Document downloaded from:

http://hdl.handle.net/10251/37066

This paper must be cited as:

Cuenca, L.; Boza Garcia, A.; Alemany Díaz, MDM.; Trienekens, JJ. (2013). Structural elements of coordination mechanisms in collaborative planning processes and their assessment through maturity models: Application to a ceramic tile company. Computers in Industry. 64(8):898-911. doi:10.1016/j.compind.2013.06.019.

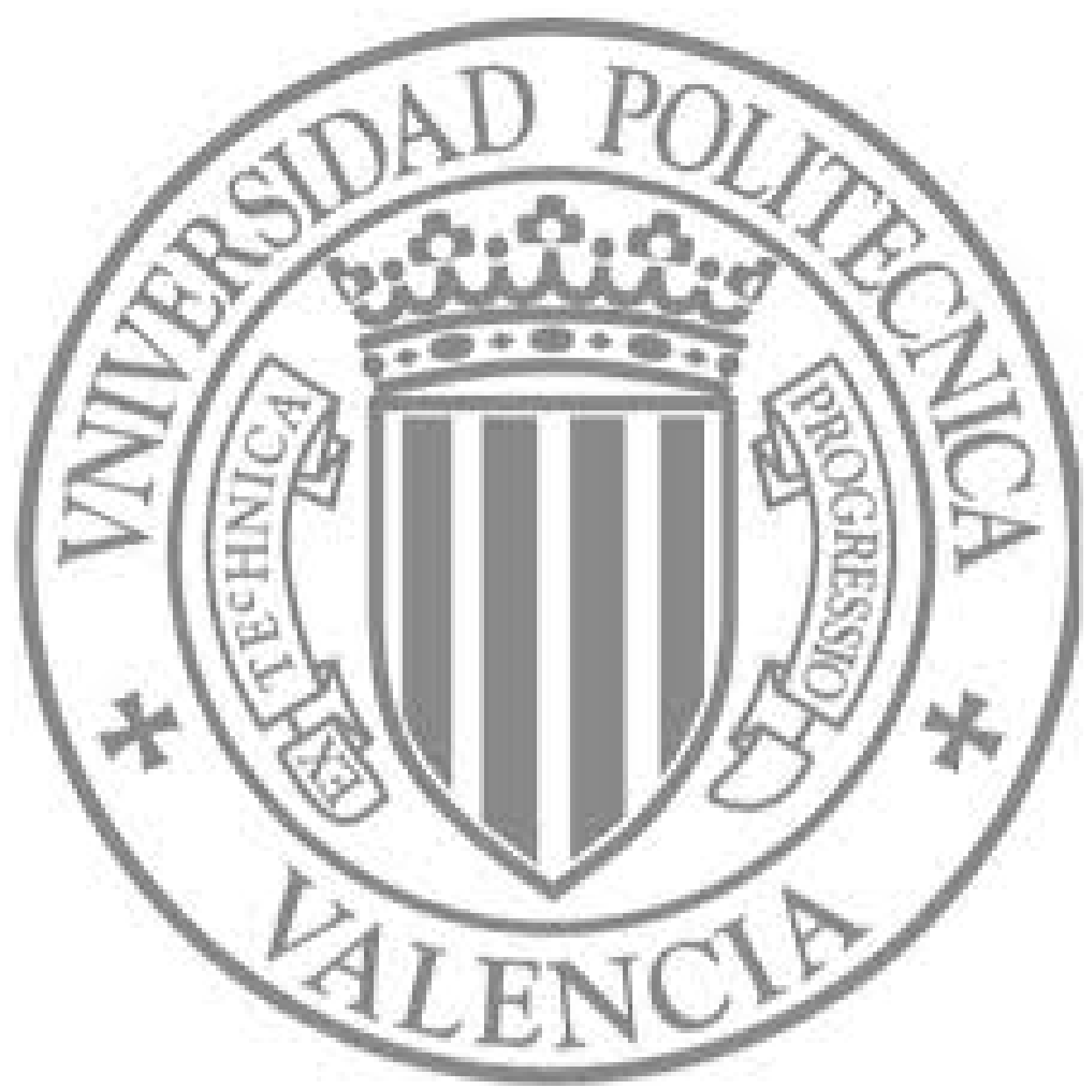

The final publication is available at

http://dx.doi.org/10.1016/j.compind.2013.06.019

Copyright Elsevier 


\title{
Structural elements of coordination mechanisms in collaborative planning processes and their assessment through maturity models: Application to a ceramic tile company
}

\author{
Llanos Cuenca ${ }^{\mathrm{a}, *}$, Andrés Boza ${ }^{a}$, M.M.E. Alemany ${ }^{\mathrm{a}}$, Jos J.M. Trienekens ${ }^{\mathrm{b}}$ \\ ${ }^{a}$ Research Centre on Production Management and Engineering (CIGIP), Universitat Politècnica de València, Camino de Vera s/n, 46022 Valencia, Spain \\ ${ }^{\mathrm{b}}$ University of Technology Eindhoven, Eindhoven, The Netherlands
}

\section{Keywords:}

Maturity model

Collaborative planning

Structural elements of coordination

mechanisms

\begin{abstract}
A B S T R A C T
Maturity is defined as a measure to evaluate the capabilities of an organization in regards to a certain discipline. The Collaborative Planning Process is a very complex process and Coordination mechanisms are especially relevant in this field to align the plans of the supply chain members. The objective of this paper is to develop a maturity model and a methodology to perform assessment for the Structural Elements of Coordination Mechanisms in the Collaborative Planning Process. Structural elements are specified in order to characterize coordination mechanisms in a collaborative planning context and they have been defined as key areas to be assessed by the maturity model. The identified structural elements are: number of decision-makers, collaboration level, interdependence relationships nature, interdependence relationships type, number of coordination mechanisms, information exchanged, information processing, decision sequence characteristics and stopping criteria. Structural elements are assessed using the scheme of five levels: Initial, Repeatable, Defined, Managed and Optimized. This proposal has been applied to a ceramic tile company and the results are also reported.
\end{abstract}

\section{Introduction}

Collaborative planning (CP) can be defined as a joint decision making process for aligning plans of individual Supply chains (SC) members with the aim of achieving a certain degree of coordination [1]. Coordination means identification and classification of existing interdependencies [2]. Different coordination processes manage different types of interdependencies. Coordination should be considered different from integration, coordination takes the target for granted and integration often involves determining this target simultaneously with the aligning of allocation decisions [3]. Generally, the execution of process depends on proper information management. Coordination mechanisms in SC should be tools by which, every member of a SC can achieve more benefits. Thus, organizations need to develop strategically aligned capabilities not only within the company itself, but also among the organizations that are part of their value-adding networks. Additionally, processes are now viewed as assets requiring investment and

\footnotetext{
* Corresponding author. Tel.: +34 963877680.

E-mail addresses: llcuenca@cigip.upv.es (L. Cuenca), aboza@cigip.upv.es (A. Boza), mareva@cigip.upv.es (M.M.E. Alemany), J.J.M.Trienekens@tue.nl (Jos J.M. Trienekens).
}

development as they mature. Thus, the concept of process maturity is becoming increasingly important as firms adopt a process view of the organization [4].

Maturity Models (MMs) describe the evolution of a specific entity over time. MMs have been developed to assess specific areas against a norm. The entity, collaboration level, in a SC can evolve over time, and MMs can show and measure this evolution. They can offer benefits to Structural Elements (SE) of Coordination Mechanisms (CM) (hereafter SECM). The main objective in the application of MMs is to assess organizations to know their maturity level with respect to a set of best practices, in this case SECM. MMs are based on the description of processes that must be implemented to achieve the level of excellence corresponding to the maximum level of maturity. Achieving each level of maturity enables an incremental and lasting improvement in performance [5]. MMs can be used as: snapshot, a representation of the as-is situation (i.e. an evaluative and comparative basis for improvement); recommendation for action (i.e. in order to derive an informed approach for increasing the capability of a specific area within an organization), instrument for controlling (i.e. measuring the success of an action) [6]. According to Santos et al. [7] a MM should serve as an assessment tool to evaluate the maturity of different organizations not only in terms of interoperability but also collaboration capabilities per se. This assessment could be 
performed by an external auditor or carried out by the target organization through self-assessment. In both cases the fulfilment of certain practices will be evaluated.

The objective of this paper is to develop a maturity model for the structural elements of coordination mechanisms in the collaborative planning process (SECM-MM) to be aware of the current situation and identify the next steps to improve the process.

The paper is structured as follows: firstly, Section 2 characterizes the different maturity model on process development, interoperability and collaboration, and business and IT strategic alignment, Section 3 defines the structural elements of collaborative planning coordination mechanisms; Section 4 proposes a $\mathrm{MM}$ for the structural elements of coordination mechanisms in the collaborative planning process and a methodology for its development and application; the MM describes the best practices that correspond to each maturity level. Section 5 shows the application to a ceramic tile company and the results obtained. The findings of the proposal are depicted in Section 6 and finally, the conclusions and future research lines are given in Section 7.

\section{Characterization of different maturity models}

A MM is a framework that describes, for a specific area of interest, a number of levels of sophistication at which activities in this area can be carried out [8]. Maturity as a measure to evaluate the capabilities of an organization in regards to a certain discipline has become popular since the Capability Maturity Model (CMM) proposed by the Software Engineering Institute at Carnegie Mellon University [9]. Whilst the original CMM has a specific focus on the evaluation of software development processes, this model has been modified and extended to different approaches and it is now applied for the evaluation of IT Infrastructure Management, Enterprise Architecture Management and Knowledge Management, to name a few.

Many authors in the field of SC management have demonstrated the existence of links between maturity levels and SC performance $[4,6,10-12]$.

The MMs analyzed have been: The capability maturity model (CMM) $[9,13]$, business and IT alignment is Luftman's maturity model [14], ICoNOs maturity model [15], Levels of Information Systems Interoperability' (LISI) [16], EIMM [17], Supply Chain Management Maturity Model, SCM-MM [4], SCOR MM [11], ECMM [8], Paché and Spalanzani [18] and MMEI [19].

CMM: The capability maturity model (CMM) has been developed to present sets of recommended practices in a number of key process areas that have been shown to enhance softwaredevelopment and maintenance capability. The Software CMM has been retired in favour of the CMM Integration (CMMI) model. CMM introduced the concept of five maturity levels defined by cumulative requirements.

Luftman's Maturity Model: It discusses an approach for assessing the maturity of the business-IT alignment.

IcoNOsMM: The structure of the IT-enabled Collaborative Networked Organizations MM (ICoNOs MM) is based on CMMI, the relationship of network organizations are studied in perspective of business-IT alignment (B-ITa).

LISI defines five levels of interoperability relating the kinds of systems involved in the interoperability process.

EIMM deals specifically with enterprise assessment, which mainly concerns the organizational barriers to interoperability. The method defines a set of areas of concerns and a set of maturity levels that provide the means to determine the current ability of an enterprise to collaborate with external entities and to specify the path to improve this ability.
SCM-MM conceptualizes how process maturity relates to the SCOR (Supply Chain Operations Reference) framework; the five stages of maturity show the progression of activities towards effective SCM and process maturity.

SCOR MM: The maturity classification proposed in the SC Operations Reference (SCOR) model relates to companies' ability to manage the full scope of a SC.

ECMM identifies four maturity levels related to the enterprise collaboration.

Paché and Spalanzani have proposed five levels of maturity built around inter-organizational SC relationships, including any relevant societal aspects.

MMEI Maturity Model for Enterprise Interoperability: It discusses how the MMEI model can be used to help enterprises evaluating the suitability of partners in an interoperability context. It also explains how sources of interoperability problems could be identified early during the design phase and so, could be solved before interoperability occurs.

CMM model is process oriented but not specify for the collaboration aspects in an inter-organizational context. The MM proposed by SCOR is limited to inter-organizational aspect of a specific chain and does not specify multi-chain aspects such as the collaboration processes or resource sharing, neither the social dimension and the necessary collaboration with territories. The model proposed by Paché and Spalanzani includes both societal and multi-chain perspectives [5]. LISI, EIMM and MMEI tackle the enterprise interoperability assessment from different point of views: LISI is mainly oriented to a technological perspective in enterprise interoperability; EIMM focuses on the common understanding of the enterprise artefacts needed to achieve interoperability on the different levels (understanding and relating different enterprise models, defining cross-organizational business process models, agree on service interfaces over which the partners communicate and exchange messages). MMEI is centred in the Interoperability barriers (conceptual, technological and organizational) and the enterprise concerns (business, process, service and data). The assessment in enterprise collaboration is covered by ECMM, it focuses on different disciplines that an organization can address to improve its business in a networked environment. Regarding business and IT strategic alignment, Luftman's MM is mainly directed to an individual company whereas IcoNOsMM is focussed to network organizations.

All MMs have common characteristics: the definition of key areas or domains to be assessed and the maturity level for each key area or domain. According to this point, we propose the definition of the maturity meta-model (Fig. 1). The maturity assessment represents a picture at a certain point in time. At that moment, the domain or key area will be assigned to a maturity level and only one.

Table 1 shows a review of different MMs according to different characteristics (1) Origin of the Model, (2) Domains or Key areas and (3) Maturity Levels. Origin of the model refers to the area to

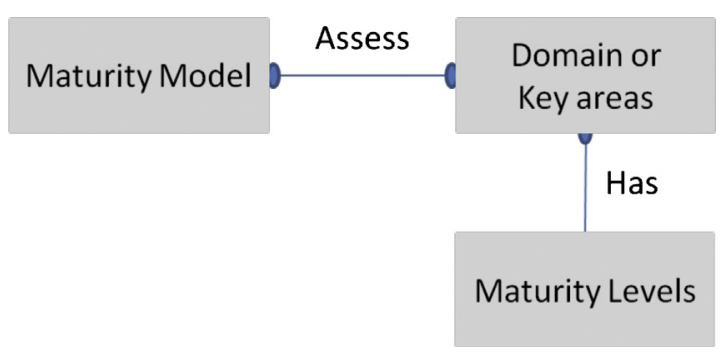

Fig. 1. Maturity meta-model. 
Table 1

Maturity models review.

\begin{tabular}{|c|c|c|c|c|c|}
\hline Maturity model & References & Year & Origin of the model & Domains or key areas & Maturity levels \\
\hline CMM & [9] & 1993 & Process development & $\begin{array}{l}\text { 1. Process Management } \\
\text { 2. Project Management } \\
\text { 3. Engineering } \\
\text { 4. Support }\end{array}$ & $\begin{array}{l}\text { Level 1: Initial } \\
\text { Level 2: Repeatable } \\
\text { Level 3: Defined } \\
\text { Level 4: Managed } \\
\text { Level 5: Optimized }\end{array}$ \\
\hline LISI & [16] & 1998 & Interoperability process & $\begin{array}{l}\text { 1. Levels of Information Systems } \\
\text { Interoperability } \\
\text { (Technology emphasis) }\end{array}$ & $\begin{array}{l}\text { Level } 0 \text { - Isolated systems } \\
\text { Level } 1 \text { - Connected. Peer-to-peer } \\
\text { Level } 2 \text { - Functional. Distributed } \\
\text { Level } 3 \text { - Domain. Integrated. } \\
\text { Level } 4 \text { - Enterprise. }\end{array}$ \\
\hline Luftman‘sMM & [14] & 2000 & Business and IT alignment & $\begin{array}{l}\text { 1. Communications } \\
\text { 2. Competency/Value } \\
\text { 3. Governance } \\
\text { 4. Partnership } \\
\text { 5. Scope and Architecture } \\
\text { 6. Skills }\end{array}$ & $\begin{array}{l}\text { Level 1: Initial/Ad Hoc Process } \\
\text { Level 2: Committed Process } \\
\text { Level 3: Established Focused Process } \\
\text { Level 4: Improved/Managed Process } \\
\text { Level 5: Optimized }\end{array}$ \\
\hline EIMM & [17] & 2003 & Enterprise interoperability & $\begin{array}{l}\text { 1. Business Strategy and Processes. } \\
\text { 2. Organization and Competences. } \\
\text { 3. Products and Services } \\
\text { 4. Systems and Technology. } \\
\text { 5. Legal Environment, Security } \\
\text { and Trust. } \\
\text { 6. Enterprise Modelling. }\end{array}$ & $\begin{array}{l}\text { Level 0: Performed } \\
\text { Level 1: Modelled } \\
\text { Level 2: Integrated } \\
\text { Level 3: Interoperable } \\
\text { Level 4: Optimized }\end{array}$ \\
\hline SCOR MM & [11] & 2004 & $\begin{array}{l}\text { Companies' ability to manage } \\
\text { the full scope of a supply chain }\end{array}$ & $\begin{array}{l}\text { 1. Plan } \\
\text { 2. Source } \\
\text { 3. Make } \\
\text { 4. Deliver }\end{array}$ & $\begin{array}{l}\text { Level 1: Functional integration } \\
\text { Level 2: Internal integration } \\
\text { Level 3: External integration } \\
\text { Level 4: Inter-company collaboration }\end{array}$ \\
\hline SCM-MM & {$[4]$} & 2004 & Supply Chain Management & $\begin{array}{l}\text { 1. Supply chain management } \\
\text { (in terms of predictability, capability, } \\
\text { control, effectiveness and efficiency) }\end{array}$ & $\begin{array}{l}\text { Ad-hoc } \\
\text { Defined } \\
\text { Linked } \\
\text { Integrated } \\
\text { Extended }\end{array}$ \\
\hline IcoNOs MM & [15] & 2006 & $\begin{array}{l}\text { Business-IT alignment in } \\
\text { network organizaton }\end{array}$ & $\begin{array}{l}\text { 1. Partnering structure } \\
\text { 2. IS architecture } \\
\text { 3. Process architecture } \\
\text { 4. Coordination }\end{array}$ & $\begin{array}{l}\text { Level 1: Incomplete } \\
\text { Level 2: Isolated } \\
\text { Level 3: Standardized. } \\
\text { Level 4: Quantitatively Managed } \\
\text { Level 5: Optimized }\end{array}$ \\
\hline Paché and Spalanzani & {$[18]$} & 2007 & $\begin{array}{l}\text { Inter-organizational supply } \\
\text { chain relationships, }\end{array}$ & $\begin{array}{l}\text { 1. Societal and multi-chain } \\
\text { perspectives. }\end{array}$ & $\begin{array}{l}\text { Level 1: intra-organizational maturity } \\
\text { Level 2: inter-organizational maturity } \\
\text { Level 3: extended inter-organizational } \\
\text { maturity } \\
\text { Level 4: multi-chain maturity } \\
\text { Level 5: societal maturity }\end{array}$ \\
\hline ECMM & [8] & 2010 & Enterprise collaboration & $\begin{array}{l}\text { 1. Innovation Project and Product } \\
\text { 2. Management } \\
\text { 3. Business } \\
\text { 4. Process and Strategy } \\
\text { 5. Customer Collaboration, } \\
\text { 6. Legal environment and Trust } \\
\text { 7. Organization Systems and technology }\end{array}$ & $\begin{array}{l}\text { 1. Performed } \\
\text { 2. Managed } \\
\text { 3. Standardized } \\
\text { 4. Innovating }\end{array}$ \\
\hline MMEI & [19] & 2011 & Enterprise Interoperability & $\begin{array}{l}\text { 1. Interoperability barriers and } \\
\text { Enterprise concerns perspectives }\end{array}$ & $\begin{array}{l}\text { 1) Unprepared } \\
\text { 2) Defined } \\
\text { 3) Aligned } \\
\text { 4) Organized } \\
\text { 5) Adaptive }\end{array}$ \\
\hline
\end{tabular}

which the model is addressed, domains or key areas refer to the different elements to be assessed through the maturity levels. The result of the assessment gives the organization an image of where they are and where they must go. The interpretation of each maturity level will be different for each key area or criterion. This rating system will help the entity to assess their level of maturity. The analyzed models nearly match in maturity levels; they are all based on the CMM levels. However, we must emphasize that the domains or key areas where they apply these models are different because the measure target is different. 
No results were found about MMs applied to SECM in collaborative planning processes. To fill this gap a MM for the SECM is proposed in Section 4.

SECM will be described in the next section. These elements will correspond with the Domains or Key areas to be assessed.

\section{Structural elements of the coordination mechanism definition (SECM)}

In a collaborative distributed context there are different decision-makers that should share some information. Additionally, in case negotiation exists, decision-makers should make several decision cycles involving repetitive sequence of decisions until a stopping criterion is achieved. In this situation, the knowledge about the process results essential. Indeed, different authors [2023 ] strength the importance of analyzing the collaboration under a process perspective. These CP processes are specifically designed for particular situations being necessary a generic approach that help in the definition, characterization and analysis of CP processes in general. In this sense, Alarcón et al. [24] conclude that a process will be defined when the answers to the following questions are known: (a) What activities are to be carried out? (b) Who is responsible to carry them out and with what? (c) When and how are they to be carried out? (d) The process inputs, (e) The process outputs, (f) The process objectives, and (g) The performance indicators.

Through the CP process approach it is possible to implement the coordination mechanisms that link the SC members' plans. In this sense, Gaudreault et al. [25] consider that the coordination mechanisms states how the SC members' relationship is operationalized (e.g. rules and protocols to exchange information, which decisions must be taken, by whom and when). Schneeweiss [26] affirms that the coordination mechanisms for Distributed Decision-Making systems in a two-level hierarchical environment are: anticipation, instruction and reaction. Arshinder and Deshmukh [27] categorize the supply network (SN) coordination mechanisms into four classes: SN contracts, Information Technology, Information Sharing and Joint Decision Making. Li and Wang [28] affirm that a coordination mechanism for a decentralized SN system should include at least three components: (i) an operational plan to coordinate the decisions and activities of SN members, (ii) a structure to share information among the members, (iii) an incentive scheme to allocate the benefits of coordination so as to entice the cooperation of all members. Stadtler [1] states that the interaction between the parties involved in a CP scheme can be documented by a protocol defined by the following structural elements: the incorporation or not of a mediator, the initial solution, the number of rounds and the number of offers to be exchanged (stopping criteria) and the final results SN members can expect. In the context of agent technology applied to $\mathrm{CP}$, Forget et al. [29] present the main characteristic of automated negotiations (collaboration level, number of participants, number of issues, decision sequence and learning ability), decision mechanisms that can be followed by agents (game theoretic negotiation, argumentation-based negotiation, auctions and heuristic based negotiation). Forget et al. [30] propose an approach that breaks from the hypothesis that planning must always be conducted in the same way. By using multi-behaviour agents they propose to provide planning agents with the ability to adapt their planning behaviours according to changes in the environment.

The structural elements help to characterize coordination mechanisms in a collaborative planning context. The identified elements are the following:

(1) Number of decision-makers [1,29,31]: it makes reference to the number of supply chain members that are either under the responsibility of a SC planning domain at a certain planning temporal level or should coordinate and integrate the different plans of other decision makers (a mediator). It is of relevance the distribution of the decision-makers along the SC tiers and the number of decision-makers in each one. The most common situations discussed in the literature [30] are centred on a two tier SC and are the following: one-to-one, one-to-many and many-to-many negotiations.

(2) Collaboration level [26,29,31,32]: it represents the degree of interest in decision makers' performance vs the SC performance as a whole.

(3) Interdependence relationships nature [1,26,31]: the sharing of power between SC decision makers could be not homogeneous. The relative position of each decision-maker in the SC depends on different factors that impact the influence of each decision-maker in the definition of the interdependence relationships. Two differentiate cases could be distinguished:

(a) Hierarchical: the sharing of power between SC members is not homogeneous and, then, $\mathrm{CP}$ interdependence relationships are dominated by decision makers with more power in the SC. Their leadership could be reflected in the interdependence relationships in several ways (e.g. defining the negotiation stopping criteria)

(b) Non-hierarchical: all the SC members are recognized with the same power and, therefore, all the interdependence relationships are equally agreed.

(4) Interdependence relationships type [31,33,34]: because SC planning decisions are made at different temporal levels and at each temporal level different decision-makers could exist, two different types of plans integration should be distinguished:

(a) Temporal integration: it involves coordinating planning decisions across different timescales or across various levels of decision-making (tactical and operational). This collaboration type is always hierarchical.

(b) Spatial integration: it involves coordinating the plans of different decision makers at the same temporal level. Depending on the sharing of the power between SC members it could be hierarchical or non-hierarchical.

(5) Number of coordination mechanisms [1,29,31]: it refers to the number of different protocols under which the different decision-makers interact.

(a) Unique: there is an only one protocol that is independent on the environment and other situation characteristics.

(b) Various: when the environment is characterized by high levels of variability, it can be advantageous to define different coordination mechanisms to work under different scenarios. In this case, different options exists:

(i) Pre-defined (non-learning ability): the number of coordination mechanisms are defined in advanced. The situations under which a specific mechanism should be employed and their characteristics should be specified.

(ii) Not pre-defined (learning ability): the decision-makers have the ability to acquire experience from previous negotiations (i.e. they are able to adapt their strategies with changing opponents, topics, concerns and user preferences) and to adapt to the context. They can modify their local planning behaviours and/or in concordance with the rest of the decision-makers.

(6) Information exchanged [1,26,29,31,32,34]: for each coordination mechanism the information exchanged between the decision-makers can make reference to SC attributes and decision-makers' outputs:

(a) SC attributes: they consist of known characteristics of the planning SN elements and their environment (demand forecasts, capacity of facilities, operating costs, incentives, 
penalizations, etc.). It is known in the literature as information sharing.

(b) Decision-makers' outputs: they are those decision variables/ criteria values which, in some way, are passed to other decision-makers. This output data becomes input data for others activities, more specifically they become interdependent parameters of other planning activities. It is known in the literature as joint decision-making and it is the essence of CP. Depending on the possibility of changing the final value of the outputs by the interdependent decisionmakers, two outputs categories could be distinguished:

(i) Final Decision Variables/Criteria: their values cannot be changed under any condition during the negotiation process or, simply, because there is no negotiation.

(ii) Non-Final Decision Variables/Criteria: their values can be modified during the negotiation process due to:

- Temporal integration: disaggregation of decisions should be made for being implemented (e.g. production volume of families should be disaggregated referred to articles)

- Spatial integration: their values are adjusted before reaching the stopping criteria of the negotiation process (e.g. ordered/supplied quantities)

(7) Information processing [34]: the exchanged information for each coordination mechanism could be incorporated in different ways by each decision-maker. Part of the share information can be simply evaluated by other decision-makers (i.e. an ordered pattern can be evaluated by a supplier to know the value of his performance criteria when he does not deviate from the buyer pattern). Other exchanged information can be incorporated in the planning problem of a decision-maker by affecting his decisional space (introduction of constraints) and/ or his criteria (penalizations or incentives for deviating from a constraint)

(8) Decision sequence characteristics [1,29]: it allows define how the coordination mechanisms will be managed.

(a) Beginning of the coordination mechanism: for each coordination mechanism it is necessary to specify when beginning (period, event-driven or a mixed), and how beginning (initial solution by upstream planning, downstream planning, random, by a coordinator, etc.)

(b) Sequence of decisions: the order in which the different decision-makers act and the decisions simultaneously made by different SC members should be specified.

(9) Stopping criteria [1,26]: in case negotiation exists, the conditions for ending a coordination mechanism could be defined in terms of number of rounds, limited time and the achievement of a determined aspiration level related with the final results the SC members can expect.

The proposed structural elements are strongly related with the collaborative planning process. The number of decision-makers is related with the activities developed in the process identifying who is in charge of them. The collaboration level depends on the information exchanged, the objectives and the performance indicator of the supply chain. Interdependence relationship nature can affect to when and how the decisions are taken, and can also exist predominant criteria from a supply chain member imposing their objectives or performance indicators. The type or interdependencies influence when and how decisions are taken (spatial or temporal) and the exchanged information detail. The number of coordination mechanism affects mainly to the number of activities defined, specially decisional activities, and it must be taken into account that different coordination mechanism can have different objectives and performance indicators. The decision process can be affected by the exchanged information process. The characteristics of the decision sequence are related with the activities of the process, the person in charge of them and when and how are executed. Finally, stopping criteria are related to the activities in the process, performance indicator associated and when and how are executed.

This analysis shows the impact of the coordination mechanisms on the $\mathrm{CP}$ process facilitating its properly understanding and representation. This is, indeed, the first step and constitutes the basis to either totally or partially automated the process (e.g. through agent technology) or to develop decision support tools for each SC member, (e.g. mathematical programming models).

Once these structural elements have been conceptualized we describe the maturity model.

\section{SECM-MM. Maturity model for the structural elements of coordination mechanisms in the collaborative planning process}

A methodology has been used to define the proposed maturity model. Most published maturity models are only based on practices and success factors from projects that showed good results in an organization or industry, but which lack a sound theoretical basis and methodology [35]. However, we can find studies that have dealt with the methodological approach in the maturity model develop. The maturity model methodology includes (in most of cases) the following phases: scope, design, populate, evaluate, deploy and maintain [8,15,36-42].

The proposed maturity model has been developed according to these phases (Fig. 2).

\subsection{Scope: SECM-MM identification}

The most significant decision in this phase involves the focus of the model. Focus refers to which domain the maturity model would be targeted and applied.

In this proposal the focus of the model is the Structural Elements of Coordination Mechanisms in the collaborative planning process.

\subsection{Design: SECM-MM elaboration}

The design of the model incorporates the needs of the intended audience and how these needs will be met. The needs of the intended audience are reflected in why they seek to apply the model, how the model can be applied to varying organizational structures, who needs to be involved in applying the model and what can be achieved through application of the model [36].

According to the maturity meta-model defined in Fig. 1, we have defined the key areas or domains to be assessed and the maturity level for each key area or domain. As it said before, the

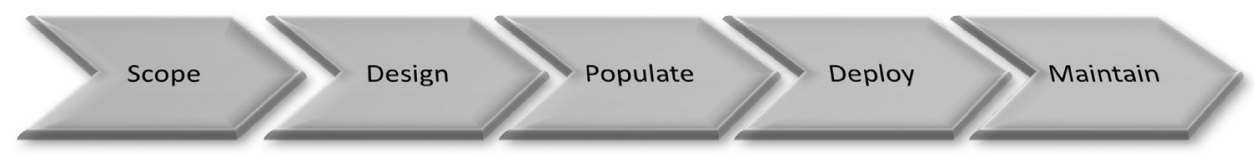

Fig. 2. Maturity model method

Adapted from de [35,36,42]. 
Table 2

Maturity level definition in SECM maturity model.

\begin{tabular}{|c|c|}
\hline SECM-M Levels & Definitions \\
\hline Level 1: Initial & $\begin{array}{l}\text { The information required and the process of the exchange information have not been identified or defined. Decision makers and sequence of } \\
\text { decision have not been identified. }\end{array}$ \\
\hline Level 2: Repeatable & $\begin{array}{l}\text { Some of the information required and the process of the exchange information have been identified or defined. Some decision makers and } \\
\text { sequence of decision have been identified. }\end{array}$ \\
\hline Level 3: Defined & $\begin{array}{l}\text { The majority of the information required and the process of the exchange information have been identified or defined. The majority of } \\
\text { decision makers and sequence of decision have been identified in the collaborative process. }\end{array}$ \\
\hline Level 4: Managed & Once the required information has been completely defined it is used and accepted between all the members. \\
\hline Level 5: Optimized & he extent of definition, use and satisfaction reach the higher level between all the members in the collaborative process. \\
\hline
\end{tabular}

origin of the model refers to the area to which the model is addressed, in this case we propose a MM for the Structural Elements of Coordination Mechanisms in the collaborative planning process. The domains or key areas correspond to the structural elements defined in Section 3.

In this particular case, the maturity model is necessary because of the impact the coordination mechanisms on the collaborative planning process (why), the model design strikes an appropriate balance between the complex reality and model simplicity therefore the model can be applied to different organizational structures and it can involve internal and external members of the organization (how and who). The proposed maturity model follows the common design principle to represent maturity as a number of cumulative stages where higher stages build on the requirements of lower stages with 5 (optimized) representing high maturity and 1 (initial) low (what).

According to [36] it is important that the final stages are distinct and well-defined, and a logical progression through stages. Stage or levels definitions should be developed to expand stage names and provide a summary of the major requirements and measures of the stage, especially those aspects that are new to the stage and not included as elements of lower stages. Table 2 describes the different maturity levels, and Table 3 summarizes the characteristics of the MM.

\subsection{Populate: SECM-MM construction}

In this phase it is necessary to identify in detail what needs to be measured in the maturity assessment and how this can be measured. The goal is to collect all relevant criteria that are necessary for the assessment of the specific domain. They should be mutually exclusive and collectively exhaustive to cover all important aspects without distorting the results by redundant or overlapping components. As established methods, [36,43], list a number of research approaches that can serve as identification tools. These are e.g. literature research, Delphi studies, case studies, focus groups or interviews, documents, questionnaires.

In this proposal the starting point was the literature review giving as a result several questions that help to identify what and how assesses the level of maturity for each key area. Table 4 shows the questions derived from the literature review.

Starting from the definition of the maturity levels (Table 2) and the questions derived from the literature (Table 4), the assessment matrix was completed.

The proposed MM (Table 5) includes the best practices to be carried out on $\mathrm{CP}$ that must be implemented to achieve the maximum level of maturity in the domains or key areas defined. For example, in the key area "number of decision makers" the best situation corresponds to the higher maturity level and it will be reached when all members in the supply chain identify their decision-makers for all their supply chain tiers and mediators. Until this objective is achieved, the supply chain passes through different states to improve their decision-makers identification, each one of these states corresponds to previous maturity levels and they guide the companies in the correct path. A similar interpretation can be applied to the remaining key areas.

\subsection{Deploy: SECM-MM Implementation}

This phase includes issues such as initial organizational application and can consider the design collaborators as primary respondents. This is the first step in determining the critical issue of model generalisability and can lead to general acceptance of the model [36]. The existing literature has been centered mainly in the previous phase instead of the maturity model deployment or validating [45].

In order to accomplish the evaluation process through MMs in this phase, a methodology is proposed (Fig. 3). This methodology can be applied in other MMs, not only in the maturity model proposed in this paper. The methodology phases have been defined according to Ref. $[6,9,46]$.

In phase 1, establishing teams and assigning the key areas to each team identifies the organization cells (including persons and/or teams) involved in the assessing process. Each one of these organization cells can be responsible for the evaluation of one or more key areas. Once the assignation is done the maturity assessment will begin (Phase 2). At the end of this phase the organization cells share and analyze the results and propose improvement plans (Phase 3 ). The application of these

Table 3

Maturity model for the Structural Elements of Coordination Mechanisms in the collaborative planning process characteristics.

\begin{tabular}{|c|c|c|c|c|c|}
\hline Maturity Model & Reference & Year & Origin of the Model & Domains or Key areas & Maturity Levels \\
\hline SECM-MM & This paper & 2012 & Collaborative planning process & $\begin{array}{l}\text { 1. Number of decision-makers } \\
\text { 2. Collaboration level } \\
\text { 3. Interdependence relationships nature } \\
\text { 4. Interdependence relationships type } \\
\text { 5. Number of coordination mechanisms } \\
\text { 6. Information exchanged } \\
\text { 7. Information processing } \\
\text { 8. Decision sequence characteristics } \\
\text { 9. Stopping criteria }\end{array}$ & $\begin{array}{l}\text { Level 1: Initial } \\
\text { Level 2: Repeatable } \\
\text { Level 3: Defined } \\
\text { Level 4: Managed } \\
\text { Level 5: Optimized }\end{array}$ \\
\hline
\end{tabular}


Table 4

Questions related to the SECM.

\begin{tabular}{|c|c|c|}
\hline SECM & Questions & Reference \\
\hline 1. Number of decision-makers & $\begin{array}{l}\text { What is the distribution of the decision-makers along the SC tiers and the number of } \\
\text { decision-makers in each one? }\end{array}$ & {$[1,26]$} \\
\hline 2. Collaboration level & $\begin{array}{l}\text { What is the degree of interest in decision makers' performance? } \\
\text { Which decisions take place? }\end{array}$ & {$[1]$} \\
\hline 3. Interdependence relationships nature & $\begin{array}{l}\text { Which is the relative position of each decision-maker in the SC? } \\
\text { What are the relationships among SC members? }\end{array}$ & {$[1,26]$} \\
\hline 4. Interdependence relationships type & $\begin{array}{l}\text { What temporal level the decisions are made at? } \\
\text { What do decision-makers participate? } \\
\text { When does collaboration take place? } \\
\text { How to coordinate different time decisions? }\end{array}$ & {$[1,33]$} \\
\hline 5. Number of coordination mechanisms & $\begin{array}{l}\text { How many protocols have been defined? } \\
\text { It depends on the learning ability? }\end{array}$ & [29] \\
\hline 6. Information exchanged & What does the information exchanged refers to? & {$[26,32]$} \\
\hline 7. Information processing & $\begin{array}{l}\text { How is the exchanged information for each coordination mechanism incorporated? } \\
\text { Who is responsible for? } \\
\text { What is the information status of each SC member? }\end{array}$ & {$[1,34]$} \\
\hline 8. Decision sequence characteristics & $\begin{array}{l}\text { How will be managed the coordination mechanism? } \\
\text { Have been defined the way in which negotiation agents process information and make their decisions? }\end{array}$ & [29] \\
\hline 9. Stopping criteria & $\begin{array}{l}\text { How have the stopping criteria been defined? } \\
\text { Where and how are they used? }\end{array}$ & {$[26,44]$} \\
\hline
\end{tabular}

Table 5

SECM-MM.

\begin{tabular}{|c|c|c|c|c|c|}
\hline & Level 1: Initial & Level 2: Repeatable & Level 3: Defined & Level 4: Managed & Level 5: Optimized \\
\hline $\begin{array}{l}\text { 1. Number of } \\
\text { decision-makers }\end{array}$ & $\begin{array}{l}\text { Decision-makers have } \\
\text { not been identified }\end{array}$ & $\begin{array}{l}\text { Some SC members have } \\
\text { identified some of their } \\
\text { decision-makers }\end{array}$ & $\begin{array}{l}\text { All SC members have } \\
\text { identified some of their } \\
\text { decision-makers }\end{array}$ & $\begin{array}{l}\text { Some SC members have } \\
\text { identified their decision- } \\
\text { makers for all their SC } \\
\text { tiers and mediators. }\end{array}$ & $\begin{array}{l}\text { All SC members have } \\
\text { identified their decision- } \\
\text { makers for all their SC } \\
\text { tiers and mediators. }\end{array}$ \\
\hline $\begin{array}{l}\text { 2. Collaboration } \\
\text { level }\end{array}$ & $\begin{array}{l}\text { Hardly at all collaboration } \\
\text { (self-interested partner } \\
\text { that makes decisions } \\
\text { mainly following its } \\
\text { local goals) }\end{array}$ & $\begin{array}{l}\text { Not very close } \\
\text { collaboration (few } \\
\text { partners put the SC goals } \\
\text { before its local goals) }\end{array}$ & $\begin{array}{l}\text { Close collaboration } \\
\text { (balance) }\end{array}$ & $\begin{array}{l}\text { Very close collaboration } \\
\text { (some altruistic partners } \\
\text { that puts the SC goals } \\
\text { before its local goals) }\end{array}$ & $\begin{array}{l}\text { Extremely collaboration } \\
\text { (partners put the SC goals } \\
\text { before its local goals) }\end{array}$ \\
\hline $\begin{array}{l}\text { 3. Interdependence } \\
\text { relationships } \\
\text { nature }\end{array}$ & $\begin{array}{l}\text { The sharing of power } \\
\text { between SC decision } \\
\text { makers } \\
\text { have not been defined }\end{array}$ & $\begin{array}{l}\text { Some SC members have } \\
\text { identified their piece of } \\
\text { power (hierarchical or } \\
\text { non-hierarchical) }\end{array}$ & $\begin{array}{l}\text { All SC members have } \\
\text { identified their piece } \\
\text { of power }\end{array}$ & $\begin{array}{l}\text { SC members try to } \\
\text { improve the } \\
\text { interdependence } \\
\text { relationships }\end{array}$ & $\begin{array}{l}\text { The interdependence } \\
\text { relationships are clearly } \\
\text { known and satisfying for } \\
\text { all SC members }\end{array}$ \\
\hline $\begin{array}{l}\text { 4. Interdependence } \\
\text { relationships } \\
\text { type }\end{array}$ & $\begin{array}{l}\text { Temporal and spatial } \\
\text { coordination levels have } \\
\text { not been defined }\end{array}$ & $\begin{array}{l}\text { Some SC members have } \\
\text { defined temporal and/or } \\
\text { spatial coordination levels }\end{array}$ & $\begin{array}{l}\text { Temporal and spatial } \\
\text { coordination levels } \\
\text { have been defined }\end{array}$ & $\begin{array}{l}\text { SC members try to } \\
\text { improve the defined } \\
\text { temporal and spatial } \\
\text { coordination levels }\end{array}$ & $\begin{array}{l}\text { Temporal and spatial } \\
\text { coordination levels have } \\
\text { been defined and it is } \\
\text { satisfactory for all SC } \\
\text { members }\end{array}$ \\
\hline $\begin{array}{l}\text { 5. Number of } \\
\text { coordination } \\
\text { mechanisms }\end{array}$ & $\begin{array}{l}\text { It has not been clearly } \\
\text { defined coordination } \\
\text { protocol }\end{array}$ & $\begin{array}{l}\text { A coordination protocol is } \\
\text { defined }\end{array}$ & $\begin{array}{l}\text { A coordination protocol is } \\
\text { defined and other } \\
\text { scenarios are identified }\end{array}$ & $\begin{array}{l}\text { The coordination } \\
\text { mechanisms works under } \\
\text { pre-defined scenarios }\end{array}$ & $\begin{array}{l}\text { The coordination } \\
\text { mechanisms works under } \\
\text { a not pre-defined } \\
\text { scenarios due to the } \\
\text { learning ability of the } \\
\text { decision-makers }\end{array}$ \\
\hline $\begin{array}{l}\text { 6. Information } \\
\text { exchanged }\end{array}$ & $\begin{array}{l}\text { Some participants shared } \\
\text { information but has not } \\
\text { yet been clearly } \\
\text { established all the } \\
\text { information needs of the } \\
\text { collaborative planning } \\
\text { process }\end{array}$ & $\begin{array}{l}\text { The exchange information } \\
\text { about SC attributes is } \\
\text { defined }\end{array}$ & $\begin{array}{l}\text { The exchange information } \\
\text { about SC attributes and } \\
\text { decision-makers' outputs } \\
\text { (decisions, criteria) are } \\
\text { defined }\end{array}$ & $\begin{array}{l}\text { The exchange information } \\
\text { about SC attributes and } \\
\text { decision-makers' outputs } \\
\text { arrive to the correct } \\
\text { decision-makers. }\end{array}$ & $\begin{array}{l}\text { The exchange information } \\
\text { about SC attributes and } \\
\text { decision-makers' outputs } \\
\text { arrive to the correct } \\
\text { decision-makers at the } \\
\text { right time }\end{array}$ \\
\hline $\begin{array}{l}\text { 7. Information } \\
\text { processing }\end{array}$ & $\begin{array}{l}\text { The processing of the } \\
\text { exchange information } \\
\text { has not been defined }\end{array}$ & $\begin{array}{l}\text { Some SC members have } \\
\text { defined their processing of } \\
\text { the exchange information }\end{array}$ & $\begin{array}{l}\text { All SC members have } \\
\text { defined their processing of } \\
\text { the exchange information }\end{array}$ & $\begin{array}{l}\text { All SC members have } \\
\text { defined their processing of } \\
\text { the exchange information } \\
\text { and use them collecting } \\
\text { exchange information and } \\
\text { providing decision- } \\
\text { makers' outputs }\end{array}$ & $\begin{array}{l}\text { All SC members have } \\
\text { defined their processing of } \\
\text { the exchange information } \\
\text { and use them in a } \\
\text { intensive way }\end{array}$ \\
\hline $\begin{array}{l}\text { 8. Decision sequence } \\
\text { characteristics }\end{array}$ & $\begin{array}{l}\text { The beginning and } \\
\text { sequence of decision } \\
\text { has not been defined }\end{array}$ & $\begin{array}{l}\text { The beginning and } \\
\text { sequence of decision has } \\
\text { been defined for some of } \\
\text { the coordination } \\
\text { mechanisms }\end{array}$ & $\begin{array}{l}\text { The beginning and } \\
\text { sequence of decision has } \\
\text { been defined for all the } \\
\text { coordination mechanisms }\end{array}$ & $\begin{array}{l}\text { The beginning and } \\
\text { sequence of decision has } \\
\text { been defined and are used } \\
\text { for all SC members }\end{array}$ & $\begin{array}{l}\text { The beginning and } \\
\text { sequence of decision has } \\
\text { been defined, are used and } \\
\text { satisfy all SC members }\end{array}$ \\
\hline $\begin{array}{l}\text { 9. Stopping } \\
\text { criteria }\end{array}$ & $\begin{array}{l}\text { The stopping criteria has } \\
\text { not been defined }\end{array}$ & $\begin{array}{l}\text { The stopping criteria has } \\
\text { been defined for some of } \\
\text { the coordination } \\
\text { mechanisms }\end{array}$ & $\begin{array}{l}\text { The stopping criteria has } \\
\text { been defined for all the } \\
\text { coordination mechanisms }\end{array}$ & $\begin{array}{l}\text { The stopping criteria has } \\
\text { been defined and are used } \\
\text { for all SC members }\end{array}$ & $\begin{array}{l}\text { The stopping criteria has } \\
\text { been defined, are used and } \\
\text { satisfy all SC members }\end{array}$ \\
\hline
\end{tabular}




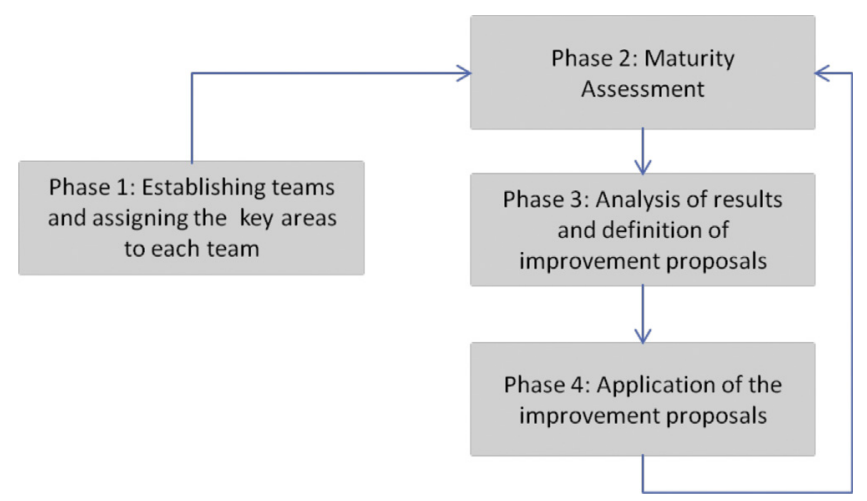

Fig. 3. Methodology for the implementation of the maturity models.

improvement plans in phase 4 is the start point to do a new assessment (phase 2).

Phase 1, 2 y 3 can be enhanced through the intensive use of technology, such as collective intelligence $[47,48]$ and on-line interview [49]. Collective intelligence is broadly defined as a group of individuals doing things collectively that seem intelligent [48]. Collective intelligence involves groups of individuals collaborating to create synergy, something greater than each individual part [50]. A type of collective intelligence is crowdsourcing. Crowdsourcing is defined by Howe [51] as "the act of taking a job traditionally performed by a designated agent (usually an employee) and outsourcing it to an undefined, generally large group of people in the form of an open call. However, mechanisms also need to be in place to protect against competition sabotaging the crowd system [48]. Sometimes relying on the crowd may not be appropriate for all actions, or all tasks. Therefore, systems that leverage the crowd for creation decisions should ensure that the final decision passes through a governing body [48]. According to Salmons [49] online interview is typically categorized according to the ability to send, received, and respond to messages at the same time, synchronous communication, or at different times, asynchronous communication. Asynchronous methods offer highquality exchanges that result when participants have a chance to think about the response, or gain new experiences between questions [52]. The communication options for preparation, interviews, and follow ups with participants can be classified into two groups text and multichannel [49]. Table 6 shows examples of these communication options.
Table 6

Communication options in online interviews.

\begin{tabular}{|c|c|c|}
\hline $\begin{array}{l}\text { Communication options } \\
\text { in online interviews }\end{array}$ & Text & Multichannel \\
\hline Asynchronous & $\begin{array}{l}\text { E-mail } \\
\text { Forum } \\
\text { Weblog } \\
\text { Wiki }\end{array}$ & $\begin{array}{l}\text { Podcast of Vodcas } \\
\text { Video } \\
\text { Visual exchange }\end{array}$ \\
\hline Synchronous & $\begin{array}{l}\text { Text message } \\
\text { Instant message } \\
\text { Chat }\end{array}$ & $\begin{array}{l}\text { Voice-Over Internet (VOIP) } \\
\text { Videoconferencing or video call } \\
\text { Shared applications }\end{array}$ \\
\hline
\end{tabular}

The proposed methodology is related to the previous one (Fig. 2) with different deployments of the same maturity model, for example on different sectors or parts of the company (Fig. 4).

\subsection{Maintain: SECM-MM evaluation and maintain}

The goal of this phase is related to the resources necessary to maintain the model's growth and use [36]. According to Helgesson et al. [53] in the assessment the objective is to understand and improve the assessment process and in the evaluation the objective is to understand and improve the maturity model in any develop phase. For example, if a model is made available via a web-interface, resources will be required over time to ensure the interface is updated to reflect changes in the underlying assessment tools. If software is developed to make the model available to consultants for third-party assisted application, software developers will need to update versions to reflect changes in the domain and technology.

In this sense, the different aspects that could be taken into account in this phase are for example:

- To promote the adaptability of the model to the required changes.

- To guarantee reporting and information exchange.

- To guarantee flexibility for growth, by incorporating key new areas or integration into another maturity model.

- To facilitate export and import of the maturity model (both structure and implementation).

\section{Implementation the SECM-MM to a ceramic tile company}

With the aim of validating the proposed model an implementation has been developed over a ceramic tile company.

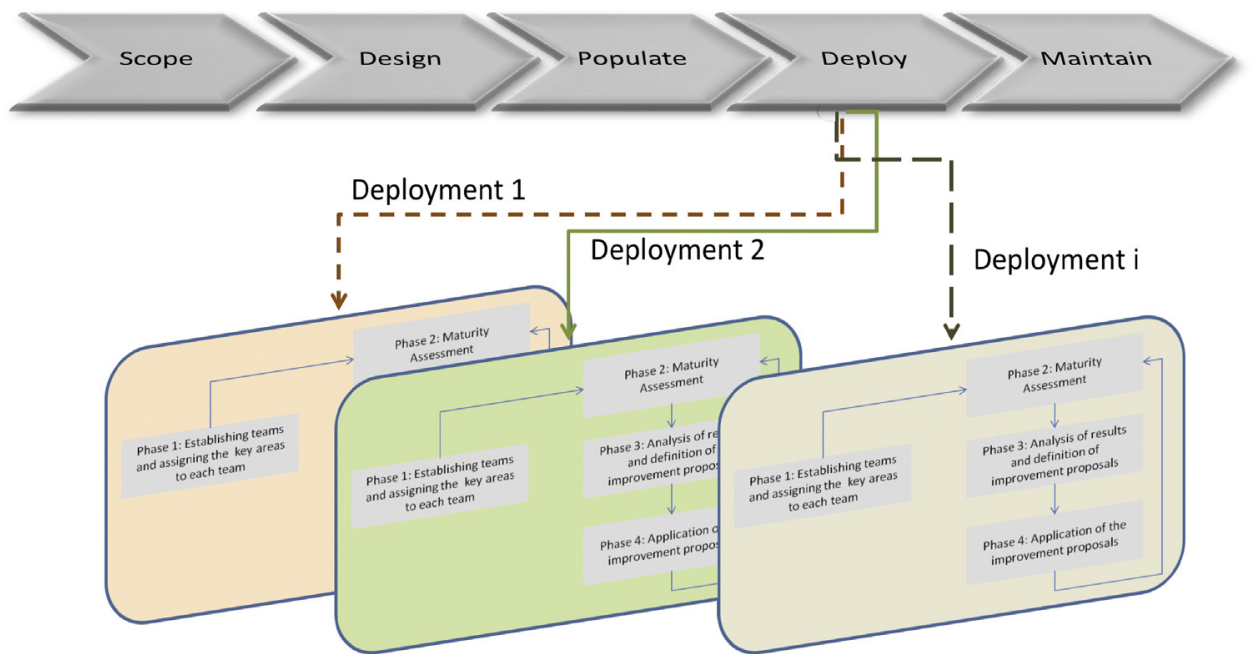

Fig. 4. Relationship between maturity model development and maturity model deployment. 


\subsection{Context}

The MM developed in this work has been verified in a Spanish ceramic SC. The Spanish ceramic industry is one of the most important at both national and international levels. In 2009, Spanish production accounted for 37\% of EU production [54]. One of the main features of the Spanish ceramic industry is the high concentration of industry in the province of Castellon (East Spain). The average production of a company in Castellón is 3 million $\mathrm{m}^{2} /$ year and outside this province is approximately $700,000 \mathrm{~m}^{2} /$ year. Globalisation, growing pressure from distant ceramic industries like those in China, and changing consumer trends, make customer satisfaction one of the keys to the successful future of the ceramic sector [55]. One of the key processes to full customer satisfaction is to prepare the SC to meet future customer demand in advance by means of correctly predicting this SC's demand and planning. Furthermore, cost minimization becomes a particularly relevant target to increase or maintain gross margins, especially in situations like the current economic crisis, in which an increase in income seems an almost impossible goal. The main contribution of this application is to show that a MM for a ceramic SC supported by this proposal makes possible to achieve a higher level in the MM of SECM The result is the maturity assessment for a Spanish ceramic SC, and the identification of those crucial aspects for the key areas.

\subsection{Problem description}

This case study involves a Spanish Industrial Group (IG) based in the province of Castellón, dedicated to the design, manufacture, marketing and distribution of white clay-based and red clay-based (glazed) ceramic flooring (technical porcelain and glazed porcelain stoneware), and white clay-based (glazed) and red clay-based (glazed) ceramic coverings since 1975. The IG has over 550 employees. It is composed of different companies which are involved in manufacturing and distributing ceramic products (with two separate and different brands) and bathroom accessories.

The company is made up of three production plants, a central warehouse and 28 selling points. Orders are prepared in the central warehouse to be dispatched and delivered to the selling points in accordance with each selling point's orders. The three production plants employ an ERP and other applications. In some cases, communication among the various participants takes place through the application shared, and across the network in other cases [56].

The logistics model of this SC can be considered multisupplier, multi-plant, multi-type-multilevel distribution centres, multi-item and multi-period [57]. At the production stage, there are several production plants that manufacture a broad catalogue of finished goods. There are finished goods with high added value that are manufactured only in production plants; others may be partly subcontracted, while some may be totally subcontracted to external suppliers (normally products with low added value). These production plants are supplied with various raw materials from different suppliers with limited supply capacity. This represents the total capacity of the supplier assigned to the SC under study because it is assumed that raw material suppliers may supply production plants belonging to other SC. The distribution of several finished goods (multi-item) from production plants to end customers is carried out in various stages (multi-level) by different types of distribution. Neither manufactured nor subcontracted finished goods can be stored in manufacturing plants. So they are sent to the first distribution level, which is made up of a number of central warehouses with limited storage capacity. Outgoing finished goods from central warehouses are designed to not only cover the demand of certain end customers (for instance, independent distributors that do not belong to the firm, construction firms, etc.), but to also supply logistics centres. Logistics centres supply finished goods to shops that have been previously assigned to them. Finally, shops, which do not have storage capacity, attend to end customers' demands. Each production plant follows a Make-ToStock strategy and it can be classified as a hybrid flow shop composed of several stages (presses-glazing lines, kilns and sorting-packing) uncoupled by buffers with limited storage capacity. Each stage is integrated by similar machines and different finished goods can be processed by each machine at each stage. Kilns represent the bottleneck section and, due to their high energy consumption and cost, the decisions related with the activation/deactivation of kilns are crucial to minimize costs. The sorting-packing section always has excess capacity and does not represent any critical resource. Changeovers from one product family to the next incur setup costs owing to the time spent in changing, for instance, moulds. These setups are especially relevant on presses-glazing lines. To minimize setup times and costs, and for commercial reasons, finished goods are grouped into product families. A product family is defined as a group of finished goods of identical use (flooring or coverings), format (size), grout (white or red), and whose preparation on production lines is similar [34].

In this sense, it is necessary to implement and evaluate the coordination mechanisms that link the network members' plans characterized through structural elements.

\subsection{Methodology}

The methodology proposed in Section 4.4 will be followed in order to apply the MM to assess practices that correspond to each maturity level.

\subsubsection{Phase 1: establishing teams and assigning the key area to each team}

The CP process is mainly concerned with the operational and tactical levels. In this case study was identified seven nodes along the process: suppliers (two nodes) which represent the supplier of glazes, one of the principal raw materials of ceramics products (tiles) and clay, manufacturing/assembly (three nodes) represent the three factories/plants. Each plant produces a specific type of products; for instance, the ceramic floor products of the catalogue's main brand; tiles for the industrial group catalogue and the ceramic products for the second brand catalogue. All the production plants can send the finished goods to the two warehouses (Wh1, Wh2) that are assigned to the distribution stage (two nodes) (Fig. 5).

Multidisciplinary teams were established with the aim of generating synergy. Each one corresponds to an organization cell with established objectives and responsibilities. The organization cells were in charge of the maturity assessment of all key areas. In order to facilitate the understanding of the model and its reliability, the composition of the organization cells were formed by experts in the node and the designers of the maturity model (in this case the paper authors). It was not considered rely on the crowd the maturity assessment, due to the characteristics of the process to be evaluated.

It was also necessary to establish an evaluation team that gathers the information, solves disagreement and is responsible for the final evaluation. It is not represented in Fig. 6 because is made up for a selection of different members belonging to different nodes.

The composition of the teams was as follows (Table 7). 


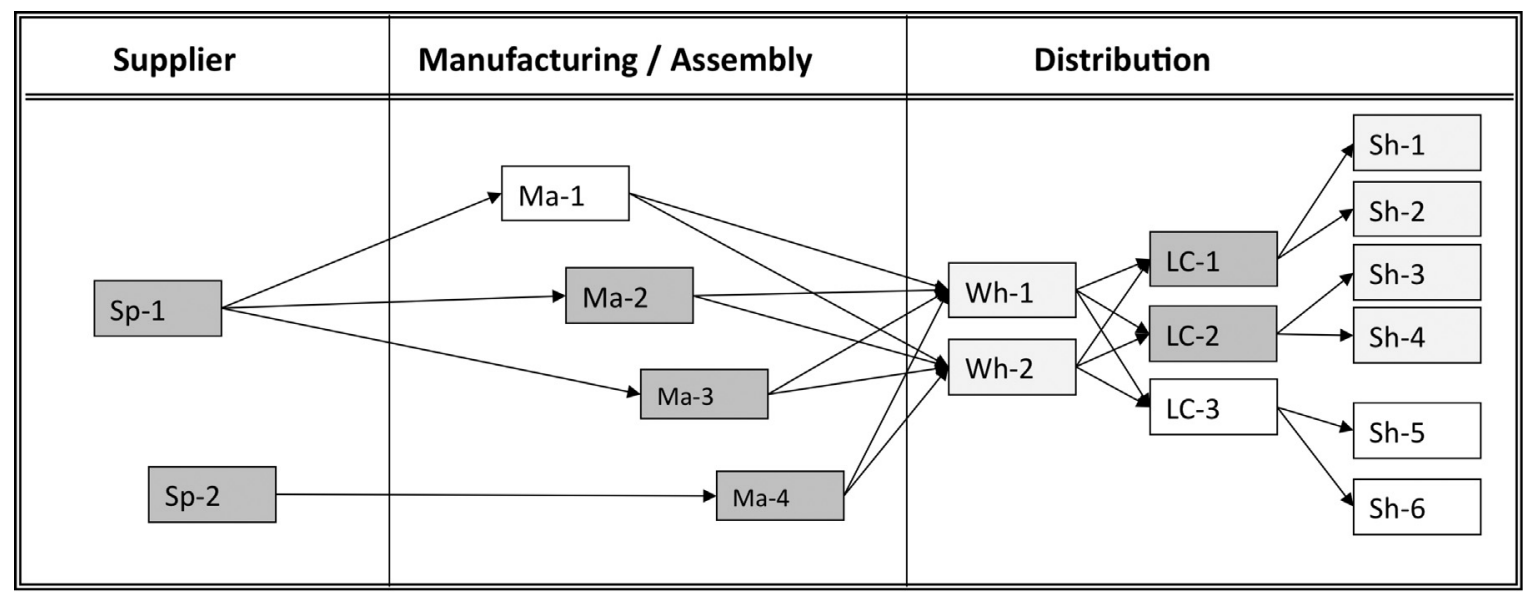

- Sp-i: Supplier number $\mathrm{i}$

- Wh-i: Warehouse number $i$

- Ma-i: Manufacturing number i

- Cl-i: Logistic Centre number i

- Sh-i: Shop number i

Fig. 5. Physical scope in the case study.

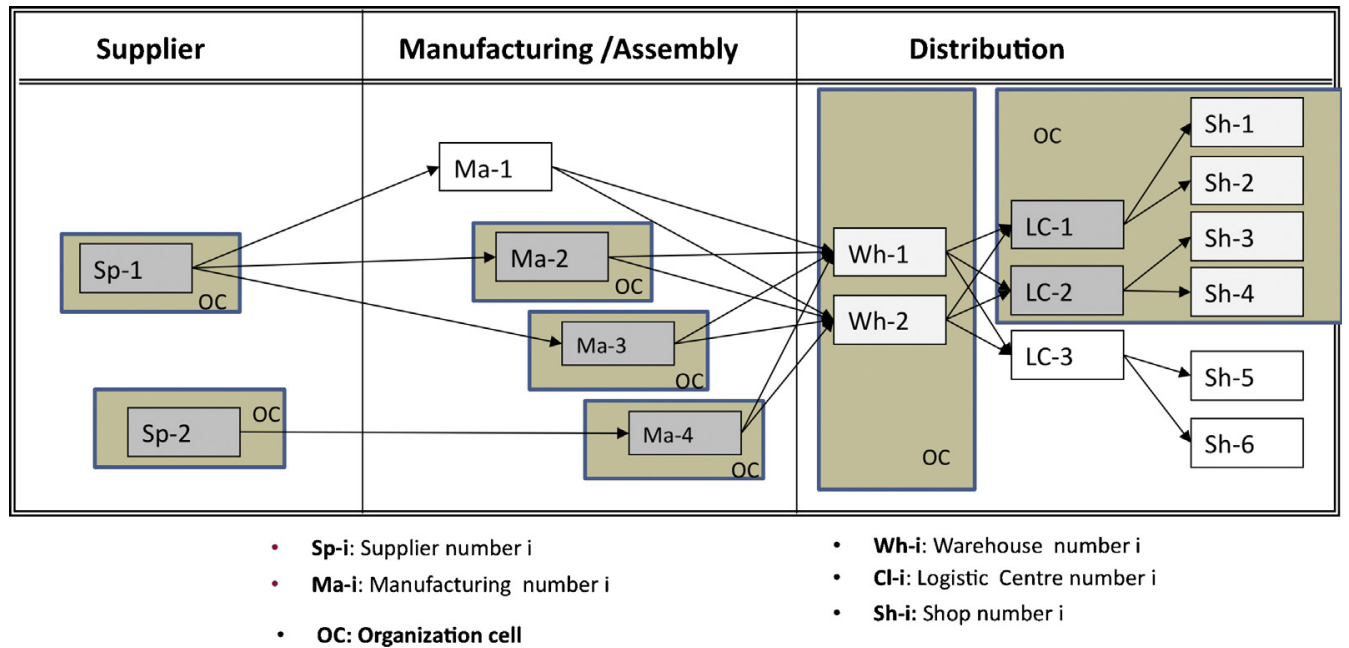

Fig. 6. Organization cells and physical scope.

Table 7

Participants in the maturity assessment.

\begin{tabular}{|c|c|c|}
\hline Code & Description & Members \\
\hline OCSp-1 & Organization cell for the supplier 1 & $\begin{array}{l}\text { People designed by the supplier } 1 \\
\text { Designer of the maturity model }\end{array}$ \\
\hline OCSp-2 & Organization cell for the supplier 2 & $\begin{array}{l}\text { People designed by the supplier } 2 \\
\text { Designer of the maturity model }\end{array}$ \\
\hline OCMa-2 & Organization cell for the plant 2 & $\begin{array}{l}\text { People designed by the plant } 2 \\
\text { Designer of the maturity model }\end{array}$ \\
\hline OCMa-3 & Organization cell for the plant 3 & $\begin{array}{l}\text { People designed by the plant } 3 \\
\text { Designer of the maturity model }\end{array}$ \\
\hline OCMa-4 & Organization cell for the plant 4 & $\begin{array}{l}\text { People designed by the plant } 4 \\
\text { Designer of the maturity model }\end{array}$ \\
\hline OCWh & Organization cell for the warehouse 1 and 2 & $\begin{array}{l}\text { People designed in the warehouse } 1 \text { and } 2 \\
\text { Designer of the maturity model }\end{array}$ \\
\hline OCLC & Organization cell for the logistic centre and shops & $\begin{array}{l}\text { People designed in the logistic centre and shops } \\
\text { Designer of the maturity model }\end{array}$ \\
\hline OCMT & Maturity team & A representative person of each node \\
\hline
\end{tabular}




\subsubsection{Phase 2: maturity assessment}

The maturity assessment process followed was: (1) each one of the structural element or key area was assessed individually by a member of the team (organization cell) to determine the level of maturity; (2) the evaluation team's decisions were discussed and agreed in a final assessment level for each key area. The process was developed through interviews and online interviews (e-mail and videoconferencing). Fig. 7 shows the result of the maturity assessment at this phase.

\subsubsection{Phase 3: analysis of results and improvements proposal}

In this phase the discussions were extremely valuable in understanding both the current state of the maturity and how they could proceed to improve it. The organization cells used the next levels of maturity as a roadmap to identify what to do next in order to obtain the highest maturity level.

The improvements proposals were

To define the implementation goals, deadlines and responsibilities.

To adapt plans of supply chain members at various levels of a planning hierarchy, adapting individual plans in an effort of joint decision making.

To define alignment plans in level and detail, defining aspects of negotiations for aligning operations.

To encourage the willingness to cooperate and to contribute to the generation of a plan that will be accepted by the SC members.

To define interdependence relationships between different entities forming the SC, as well as the information exchanged.
To establish a protocol for consistent communication.

To improve the identification the stopping criteria and to establish specific factors that allow supply chain nodes to support their own decision-making processes and to assess when the negotiation process must continue or stop.

These improvement proposals help to enhance the distribution of decision-makers along de supply chain, the degree of interest in decision makers performance, as well as the coordination mechanism definition and stopping criteria.

\subsubsection{Phase 4: application of the improvement proposals}

In order to increase the maturity level obtained in phase 2 , the improvements proposals were applied over the structural elements in the collaborative planning process. The implementation of improvements and follow-up was conducted for six months; eventually it proceeded to a reassessment of maturity levels (back to phase two). Fig. 8 shows the maturity assessment in a second evaluation.

\subsection{Results}

After three evaluations we can observe the following results. In the Key area 1, define the number of decision makers, the result (after the first evaluation) was that some SC members had identified some of their decision-makers, after the proposed improvements, all SC members had identified their decision-makers, however not for all tiers and mediators, so that the maturity level reached was "Level 3". In the third evaluation was improved but did not reach either to all tiers nor

\begin{tabular}{|c|c|c|c|c|c|}
\hline & Level 1: Initial & Level 2: Repeteable & Level 3: Defined & Level 4: Managed & Level 5: Optimized \\
\hline $\begin{array}{l}\text { 1. Number of decision- } \\
\text { makers }\end{array}$ & $\begin{array}{l}\text { Decision-makers have } \\
\text { not been identified }\end{array}$ & $\begin{array}{l}\text { Some SC members have } \\
\text { identified some ofth eir } \\
\text { decision-maket }\end{array}$ & $\begin{array}{l}\text { All SC members have } \\
\text { identified some of their } \\
\text { decision-makers }\end{array}$ & $\begin{array}{l}\text { Some SC members have } \\
\text { identified their decision- } \\
\text { makers for all their SC tiers } \\
\text { and mediators. }\end{array}$ & $\begin{array}{l}\text { All SC members have } \\
\text { identified their decision- } \\
\text { makers for all their SC tiers } \\
\text { and mediators. }\end{array}$ \\
\hline 2. Collabor ation level & $\begin{array}{l}\text { Hardly at all } \\
\text { collaboration (self- } \\
\text { interested partner that } \\
\text { makes decisions mainly } \\
\text { following its local goals) }\end{array}$ & $\begin{array}{l}\text { Not very close collab oration } \\
\text { (few partners put the SC } \\
\text { goals before its local goals) }\end{array}$ & $\begin{array}{l}\text { Close collaboration } \\
\text { (balance) }\end{array}$ & $\begin{array}{l}\text { Very close collaboration } \\
\text { (some altruistic partners } \\
\text { that puts the SC goals } \\
\text { before its local goals) }\end{array}$ & $\begin{array}{l}\text { Extremely collaboration } \\
\text { (partners put the SC goals } \\
\text { before its local goals) }\end{array}$ \\
\hline $\begin{array}{l}\text { 3. Interdependence } \\
\text { relationships nature }\end{array}$ & $\begin{array}{l}\text { The sharing of power } \\
\text { between SC deais on } \\
\text { makers havenod een } \\
\text { defined }\end{array}$ & $\begin{array}{l}\text { Some SC members have } \\
\text { identified their piece of } \\
\text { power (hierarchical or non- } \\
\text { hierarchical) }\end{array}$ & $\begin{array}{l}\text { All SC members have } \\
\text { identified their piece of } \\
\text { power }\end{array}$ & $\begin{array}{l}\text { SC members try to improve } \\
\text { the interdependence } \\
\text { relationships }\end{array}$ & $\begin{array}{l}\text { The interdependence } \\
\text { relationships are clearly } \\
\text { known and satisfying for all } \\
\text { SC members }\end{array}$ \\
\hline $\begin{array}{l}\text { 4. Interdependence } \\
\text { relationships type }\end{array}$ & $\begin{array}{l}\text { Temporal and spatial } \\
\text { coordination lev els have } \\
\text { not been defined }\end{array}$ & $\begin{array}{l}\text { Some SC members have } \\
\text { defined temporal and/or } \\
\text { spatial coordination levels }\end{array}$ & $\begin{array}{c}\text { Temporal and spatial } \\
\text { coordination lev els have } \\
\text { been defined }\end{array}$ & $\begin{array}{l}\text { SC members try to improve } \\
\text { the defined temporal and } \\
\text { spatial coordinationevels }\end{array}$ & $\begin{array}{c}\text { Temp oral and spatial } \\
\text { coordination lev els have } \\
\text { been defined and it is } \\
\text { satisfactory for all SC } \\
\text { members }\end{array}$ \\
\hline $\begin{array}{l}\text { 5. Number of } \\
\text { coordination } \\
\text { mechanisms }\end{array}$ & $\begin{array}{l}\text { It has not been clearly } \\
\text { defined coordination } \\
\text { protocol }\end{array}$ & $\begin{array}{l}\text { A coordination protocol is } \\
\text { defined }\end{array}$ & $\begin{array}{l}\text { A coordination protocol is } \\
\text { defined and other scenarios } \\
\text { are identified }\end{array}$ & $\begin{array}{l}\text { The coordination } \\
\text { mechanisms worksunder } \\
\text { pre-defined scenarios }\end{array}$ & $\begin{array}{l}\text { The coordination } \\
\text { mechanisms works undera } \\
\text { not pre-defined scenarios } \\
\text { due to the learning ability } \\
\text { of the decision-makers }\end{array}$ \\
\hline $\begin{array}{l}\text { 6.Information } \\
\text { exchanged }\end{array}$ & $\begin{array}{l}\text { Some participants shared } \\
\text { information but has not } \\
\text { yet been clearly } \\
\text { established all the } \\
\text { information need f the } \\
\text { collaborative planning } \\
\text { process }\end{array}$ & $\begin{array}{l}\text { The exchange in formation } \\
\text { about } S C \text { attributes is } \\
\text { defined }\end{array}$ & $\begin{array}{l}\text { The exchange information } \\
\text { about SC attributes and } \\
\text { decision-makers' outputs } \\
\text { (decisions, criteria) are } \\
\text { defined }\end{array}$ & $\begin{array}{l}\text { The exchange in formation } \\
\text { about } \mathrm{SC} \text { attributes and } \\
\text { decision-makers' outputs } \\
\text { arrive to the correct } \\
\text { decision-makers. }\end{array}$ & $\begin{array}{l}\text { The exchange information } \\
\text { about SC attributes and } \\
\text { decision-makers' outputs } \\
\text { arrive to the correct } \\
\text { decision-makers at the right } \\
\text { time }\end{array}$ \\
\hline $\begin{array}{l}\text { 7.Information } \\
\text { processing }\end{array}$ & $\begin{array}{l}\text { The processing of the } \\
\text { exchange information } \\
\text { has not been defined }\end{array}$ & $\begin{array}{l}\text { Some SC members have } \\
\text { defined their processing of } \\
\text { the exchange information }\end{array}$ & $\begin{array}{l}\text { All SC members have } \\
\text { defined their processing of } \\
\text { the exchange information }\end{array}$ & $\begin{array}{l}\text { All SC members have } \\
\text { defined their processing of } \\
\text { the exchange information } \\
\text { and use them collecting } \\
\text { exchange in formation and } \\
\text { providing decision-makers' } \\
\text { outputs }\end{array}$ & $\begin{array}{l}\text { All SC members have } \\
\text { defined their processing of } \\
\text { the exchange information } \\
\text { and use them in a intensive } \\
\text { way }\end{array}$ \\
\hline $\begin{array}{l}\text { 8.Decision sequence } \\
\text { characteristics }\end{array}$ & $\begin{array}{l}\text { The beginning and } \\
\text { sequence of decision has } \\
\text { not been defined }\end{array}$ & $\begin{array}{l}\text { The beginning and sequence } \\
\text { of decision has been defined } \\
\text { for some of the conffination } \\
\text { mechanisms }\end{array}$ & $\begin{array}{l}\text { The beginning and } \\
\text { sequence of decision has } \\
\text { been defined for all the } \\
\text { coordination mechanisms }\end{array}$ & $\begin{array}{l}\text { The beginning and } \\
\text { sequence of decision has } \\
\text { been defined and are used } \\
\text { for all SC members }\end{array}$ & $\begin{array}{l}\text { The beginning and } \\
\text { sequence of decision has } \\
\text { been defined, are used and } \\
\text { satisfy all SC members }\end{array}$ \\
\hline 9.Stopping criteria & $\begin{array}{l}\text { The stopping criteria has } \\
\text { not been define }\end{array}$ & $\begin{array}{l}\text { The stopp ing criteria has } \\
\text { been defined for some of } \\
\text { the coordination } \\
\text { mechanisms }\end{array}$ & $\begin{array}{l}\text { The stopping criteria has } \\
\text { been defined for all the } \\
\text { coordination mechanisms }\end{array}$ & $\begin{array}{l}\text { The stopping criteria has } \\
\text { been defined and are used } \\
\text { for all } \mathrm{SC} \text { members }\end{array}$ & $\begin{array}{l}\text { The stopping criteria has } \\
\text { been defined, are used and } \\
\text { satisfy all SC members }\end{array}$ \\
\hline
\end{tabular}

Fig. 7. Maturity assessments in a first evaluation. 


\begin{tabular}{|c|c|c|c|c|c|}
\hline & Level 1: Initial & Level 2: Repeteable & Level 3: Defined & Level 4: Managed & Level 5: Optimized \\
\hline $\begin{array}{l}\text { 1. Number of decision- } \\
\text { makers }\end{array}$ & $\begin{array}{l}\text { Decision-makers have } \\
\text { notbeen identified }\end{array}$ & $\begin{array}{l}\text { Some SC members have } \\
\text { identified some of their } \\
\text { decision-makers }\end{array}$ & $\begin{array}{l}\text { All SC members have } \\
\text { identified some of their } \\
\text { decision-mak s }\end{array}$ & $\begin{array}{l}\text { Some SC members have } \\
\text { identified their decision- } \\
\text { makers for all their SC tiers } \\
\text { and mediators. }\end{array}$ & $\begin{array}{l}\text { All SC members have } \\
\text { identified their decision- } \\
\text { makers for all their SC tiers } \\
\text { and mediators. }\end{array}$ \\
\hline 2. Collabor ation level & $\begin{array}{l}\text { Hardly at all } \\
\text { collaboration (self- } \\
\text { interested partner that } \\
\text { makes decisions mainly } \\
\text { follow ing its local goals) }\end{array}$ & $\begin{array}{l}\text { Not very close collaboration } \\
\text { (few partners put the SC } \\
\text { goals before its local goals) }\end{array}$ & $\begin{array}{l}\text { Close collaboration } \\
\text { (balance) }\end{array}$ & $\begin{array}{l}\text { Very close collaboration } \\
\text { (some altruisticpartners } \\
\text { that puts the SC goals } \\
\text { before its local goaly }\end{array}$ & $\begin{array}{l}\text { Extremely collaboration } \\
\text { (partners put the SC goals } \\
\text { before its local goals) }\end{array}$ \\
\hline $\begin{array}{l}\text { 3. Interdependence } \\
\text { relationships nature }\end{array}$ & $\begin{array}{l}\text { The sharing of power } \\
\text { between SC decision } \\
\text { makers havenot been } \\
\text { defined }\end{array}$ & $\begin{array}{l}\text { Some SC members have } \\
\text { identified their piece pf } \\
\text { power (hierarchica fnon- } \\
\text { hierarchical) }\end{array}$ & $\begin{array}{l}\text { All SC members have } \\
\text { identified their piece of } \\
\text { power }\end{array}$ & $\begin{array}{l}\text { SC members try to improve } \\
\text { the interdependence } \\
\text { relationships }\end{array}$ & $\begin{array}{l}\text { The interdependence } \\
\text { relationships are clearly } \\
\text { known and satisfying for all } \\
\text { SC members }\end{array}$ \\
\hline $\begin{array}{l}\text { 4. Interdependence } \\
\text { relationships type }\end{array}$ & $\begin{array}{l}\text { Temporal and spatial } \\
\text { coordination levels have } \\
\text { not been defined }\end{array}$ & $\begin{array}{l}\text { Some SC members have } \\
\text { defined temporal and/or } \\
\text { spatial coordination levels }\end{array}$ & $\begin{array}{c}\text { Temporal and spatial } \\
\text { coordination lev elshave } \\
\text { been defined }\end{array}$ & $\begin{array}{l}\text { SC members try to improve } \\
\text { the defined temp oral and } \\
\text { spatial coordinatiof puels }\end{array}$ & $\begin{array}{c}\text { Temporal and spatial } \\
\text { coordination lev elshave } \\
\text { been defined and it is } \\
\text { satisfactory for all SC } \\
\text { members }\end{array}$ \\
\hline $\begin{array}{l}\text { 5. Number of } \\
\text { coordination } \\
\text { mechanisms }\end{array}$ & $\begin{array}{l}\text { It has not been clearly } \\
\text { defined coordination } \\
\text { protocol }\end{array}$ & $\begin{array}{l}\text { A coordination protocol is } \\
\text { defined }\end{array}$ & $\begin{array}{l}\text { A coordination protocol is } \\
\text { defined and other scenarios } \\
\text { are identified }\end{array}$ & $\begin{array}{l}\text { The coordination } \\
\text { mechanisms works under } \\
\text { pre-defined scenarios }\end{array}$ & $\begin{array}{l}\text { The coordination } \\
\text { mechanisms works undera } \\
\text { not pre-defined scenarios } \\
\text { due to the learning ability } \\
\text { of the decision-makers }\end{array}$ \\
\hline $\begin{array}{l}\text { 6.Information } \\
\text { exchanged }\end{array}$ & $\begin{array}{l}\text { Some participants shared } \\
\text { information but has not } \\
\text { yet been clearly } \\
\text { estab lished all the } \\
\text { information needs of the } \\
\text { collaborative planning } \\
\text { process }\end{array}$ & $\begin{array}{l}\text { The exchange information } \\
\text { about SC attributes is } \\
\text { defined }\end{array}$ & $\begin{array}{l}\text { The exchange information } \\
\text { about SC attributes and } \\
\text { decision-makers' outputs } \\
\text { (decisions, criteria) are } \\
\text { defined }\end{array}$ & $\begin{array}{l}\text { The exchange information } \\
\text { about } \mathrm{SC} \text { attributes and } \\
\text { decision-makers' outputs } \\
\text { arrive to the correct } \\
\text { decision-makers. }\end{array}$ & $\begin{array}{l}\text { The exchange information } \\
\text { about SC attributes and } \\
\text { decision-makers' outputs } \\
\text { arrive to the correct } \\
\text { decision-makers at the right } \\
\text { time }\end{array}$ \\
\hline $\begin{array}{l}\text { 7.Information } \\
\text { processing }\end{array}$ & $\begin{array}{l}\text { The processing of the } \\
\text { exchange information } \\
\text { has not been defined }\end{array}$ & $\begin{array}{l}\text { Some SC members have } \\
\text { defined their processing of } \\
\text { the exchange information }\end{array}$ & $\begin{array}{l}\text { All SC members have } \\
\text { defined their processing of } \\
\text { the exchange information }\end{array}$ & $\begin{array}{l}\text { All SC members have } \\
\text { defined their processing of } \\
\text { the exchange information } \\
\text { and use them collecting } \\
\text { exchange information and } \\
\text { providing decision-makers' } \\
\text { outputs }\end{array}$ & $\begin{array}{l}\text { All SC members have } \\
\text { defined their processing of } \\
\text { the exchange information } \\
\text { and use them in a intensive } \\
\text { way }\end{array}$ \\
\hline $\begin{array}{l}\text { 8.Decision sequence } \\
\text { characteristics }\end{array}$ & $\begin{array}{l}\text { The beginning and } \\
\text { sequence of decision has } \\
\text { not been defined }\end{array}$ & $\begin{array}{l}\text { The beginning and sequence } \\
\text { of decision has been defined } \\
\text { for some of the coordination } \\
\text { mechanisms }\end{array}$ & $\begin{array}{l}\text { The beginning and } \\
\text { sequence of decision has } \\
\text { been defined for all the } \\
\text { coordination mechanisms }\end{array}$ & $\begin{array}{l}\text { The beginning and } \\
\text { sequence of d fision has } \\
\text { been defined nd are used } \\
\text { for all SC members }\end{array}$ & $\begin{array}{l}\text { The beginning and } \\
\text { sequence of decision has } \\
\text { been defined, are used and } \\
\text { satisfy all SC members }\end{array}$ \\
\hline 9.Stopping criteria & $\begin{array}{l}\text { The stopping criteria has } \\
\text { not been defined }\end{array}$ & $\begin{array}{l}\text { The stopp ing criteria has } \\
\text { been defined for some of } \\
\text { the coordination } \\
\text { mechanisms }\end{array}$ & $\begin{array}{l}\text { The stopp ing criteria has } \\
\text { been defined fall the } \\
\text { coordination mechanisms }\end{array}$ & $\begin{array}{l}\text { The stopp ing criteria has } \\
\text { been defined and are used } \\
\text { for all SC members }\end{array}$ & $\begin{array}{l}\text { The stopping criteria has } \\
\text { been defined, are used and } \\
\text { satisfy all SC members }\end{array}$ \\
\hline
\end{tabular}

Fig. 8. Maturity assessments in a second evaluation.

mediators, perhaps due to the complexity of relationships in this company.

The collaboration level (Key area 2) and Relationships Interdependence nature (Key area 4) had achieved "Level 5", perhaps in part, because the starting point in the first assessment was higher.

Highlights the result of Stopping criteria of the coordination mechanism (Key area 9) that starting from "Level 1" quickly reached the maturity "Level 5", this is because even from a situation in which the stopping criteria had not been defined, when it was, it was defined for all the coordination mechanism and with the suitable improvement proposal it was used and satisfied all SC members.

Key areas 5 and 6 (number of coordination mechanisms and Information exchanged) had a similar behaviour which may suggest that the definition and choice of the number of coordination mechanisms can be related to the information exchanged.

Regarding the Information Exchanged (Key area 6) in the first evaluation some participants shared information but had not yet been clearly established all the information needs of the collaborative planning process ("Level 1"), in some cases it had been defined the processing of the exchange information in key area 7 (Level 2).

The interdependence relationships nature (Key area 3) had a slow increase from "Level 1" where the sharing of power between SC decision makers had not been defined to "Level 3" where all SC members had identified their piece of power. At this moment the company is carrying out the activities needed to reach "Level 5" where the interdependence relationships are clearly known and satisfying for all SC members.

Finally the Key area 8, decision sequence characteristics, reached the "Level 4" (The beginning and sequence of decision has been defined and are used for all SC members) and it is in progress to achieve satisfying all SC members.

Table 8 and Fig. 9 show the evolution of the maturity assessment in the SC along three evaluations.

Table 8

Results of maturity assessments.

\begin{tabular}{|c|c|c|c|}
\hline & First evaluation & Second evaluation & Third evaluation \\
\hline 1. Number of decision makers & 2 & 3 & 3 \\
\hline 2. Collaboration level & 3 & 4 & 5 \\
\hline 3. Interdependence relationships nature & 1 & 2 & 3 \\
\hline 4. Interdependence relationships type & 4 & 4 & 5 \\
\hline 5. Number of coordination mechanisms & 1 & 2 & 3 \\
\hline 6. Information exchanged & 1 & 2 & 3 \\
\hline 7. Information processing & 2 & 2 & 3 \\
\hline 8. Decision sequence characteristics & 2 & 4 & 4 \\
\hline 9. Stopping criteria & 1 & 3 & 5 \\
\hline
\end{tabular}




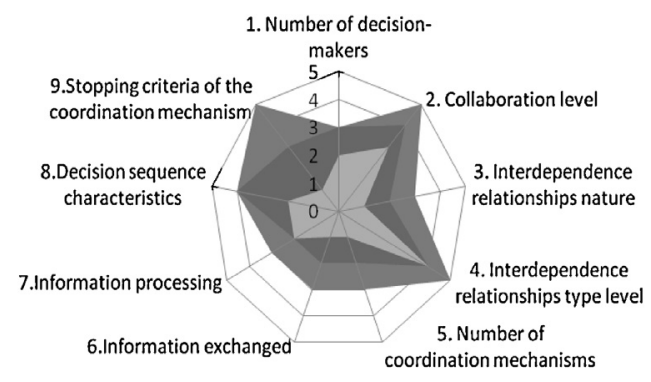

\Results after third evaluation $\square$ Results after second evaluation $\square$ Results after first evaluation

Fig. 9. Graphical representation.

\section{Findings}

This section puts forward the findings obtained with the development and deployment of the proposed maturity model.

The proposed maturity model followed a methodological approach that conducted and helped its development. This also make possible the comparison with other maturity models and identifying differences to related maturity models of the same or similar application domain. Once identified the scope of the model, one of the most important aspect was to define what needs to be measured in the maturity assessment and how this can be measured. The design process of the maturity model, the basic information and their relationships were documented and communicated in a way understandable for the people who applied the maturity model and those to whom results are reported. It is important to remark that the model could be extended including new domains or key areas to be evaluated.

The maturity model informs about the current maturity situation of the structural elements of the coordination mechanism in the collaborative planning process and provides a set of actions to improve it. The case study offers evidence that the assessment was very valuable by all the participants in the study. In some cases the assessment identified problems that were already known by some of the participants, however the assessment allowed to bring together all stakeholders in characterization of coordination mechanism with a clear summary of the strengths and weaknesses of the organization in this area.

In general the maturity model was well accepted; although sometimes the people involved in the evaluation process mentioned the necessity of adapt some capability associated to a maturity level in a determinate structural element. In this sense the maturity model should provide advice on how to adapt or configure the criteria according to different situational characteristics.

Another important aspect was the information processing. In part, the maturity model utility is based on the information processing and generated analysis. In order to provide flexibility to develop and deploy the maturity model, the collection, processing and reporting must be agile, as well as the maintenance e.g. by adding new key areas to be evaluated. In that context, we consider necessary to develop a software tool that allows on one hand the development and adaptation of generic maturity models and on the other hand allowing its implementation.

\section{Conclusions and future research lines}

Maturity models have been confirmed as an important tool for allowing a better understanding of the organization situation and help them to find the best way for change. The characterization of the main MMs on different areas has allowed their revision and identifying the need for SECM-MM. In this paper, SECM have been defined as key areas to be assessed by MM application. Each maturity level associated to each structural element corresponds to a key practice to be used. This proposal has been developed and guided by the need to enhance coordination mechanisms on the $\mathrm{CP}$ process. The MM proposed provide a framework to define, (1) the basic and essential features for establishing SECM, (2) an understanding of the key practices that need to be fully embedded and developed within the organization to achieve collaboration improvement and (3) a mechanism to help identify risks and issues that need to manage. The MM allows identifying the state on a CP process. It can be used in two aspects: (1) Historical evolution: It can be use to follow the historical evolution of the collaboration planning process and (2) Benchmarking: It can be used to compare mature model among other collaboration planning process (for instance: in other SC or the CP of other products). The application methodology guides the organizations to apply the maturity model in a structured way, identifying the organizations cells or teams in charge of assess the domain or key areas according to the best practices defined in the MM and the steps to be followed. The validation through a case study has allowed providing an example of deployment and demonstrating its utility in a real supply chain.

A future research line can be the analysis of dependencies between the SECM and if they can influence in the maturity assessment. On the other hand, following the application methodology proposed, the SECM-MM can be applied in other supply chains. Moreover the proposal can be incorporated into another maturity model with the same origin (collaborative planning process).

\section{References}

[1] H. Stadtler, A framework for collaborative planning and state-of-the-art, OR Spectrum 31 (1) (2009) 5-30.

[2] Z. Li, A. Kumar, Y.G. Lim, Supply chain modeling a coordination approach, Integrated Manufacturing Systems 13 (8) (2002) 551-561.

[3] R. Oliva, N. Watson, Cross-functional alignment in supply chain planning: a case study of sales and operations planning, Journal of Operations Management 29 (5) (2011) 434-448

[4] A. Lockamy, K. McCormack, The development of a supply chain management process maturity model using the concepts of business process orientation, Supply Chain Management: An International Journal 9 (4) (2004) 272-278.

[5] D. Estampe, S. Lamouri, J.-L. Paris, S. Brahim-Djelloul, A framework for analysing supply chain performance evaluation models, International Journal of Production Economics (2010), http://dx.doi.org/10.1016/j.ijpe.2010.11.024, http://www sciencedirect.com/science/article/pii/S0925527310004536.

[6] S. Hain, A. Back, Towards a maturity model for E-collaboration - a design science research approach, in: System Sciences (HICSS), 44th Hawaii International Conference on, 2011.

[7] I. Santos, S. Schuster, M. Vergara, J. Alonso, Assessing readiness for enterprise collaboration and enterprise interoperability, in: Proceedings of ICE Conference Lisbon, 2008.

[8] J. Alonso, I. Martínez de Soria, L. Orue-Echevarria, M. Vergara, Enterprise collaboration maturity model (ECMM): preliminary definition and future challenges, in: Enterprise Interoperability IV. Part VII, Springer, London/Dordrecht/Heidelberg/ New York, 2010, pp. 429-438.

[9] M.C. Paulk, B. Curtis, M.B. Chrissis, C.V. Weber, The Capability Maturity Model for Software, Version 1. 1 (No. CMU/SEI-93-TR-24), Software Engineering Institute, Pittsburgh, Pennsylvania, 1993.

[10] M. Simatupang, R. Sridharan, A benchmarking scheme for supply chain collaboration, Benchmarking: An International Journal 1 (1) (2004) 9-30.

[11] S. Cohen, J. Roussel, Strategic Supply Chain Management: The Five Disciplines for Top Performance, first ed., McGraw-Hill, New York, 2004.

[12] P. Trkman, M.I. Stemberger, J. Jaklic, A. Groznik, Process approach to supply chain integration, Supply Chain Management: An International Journal 12 (2) (2007) 116-128.

[13] M.C. Paulk, A history of the capability maturity model for software, Software Quality Profile 1 (1) (2009) 5-19

[14] J.N. Luftman, Assessing business-IT alignment maturity, Communications of the Association for Information Systems 4 (14) (2000) 1-51.

[15] R.G. Santana Tapia, What is a Networked Business? Technical Report Centre for Telematics and Information Technology, University of Twente, Enschede, Netherlands, 2006. 
[16] C4ISR, Architectures Working Group report Levels of Information Systems Interoperability (LISI), DoD, United States, 1998.

[17] ATHENA, Advanced Technologies for Interoperability of Heterogeneous Enterprise Networks and their Applications, FP6-2002-IST1, Integrated Project Proposal (2003).

[18] G. Paché, A. Spalanzani, La gestion deschaınes logistiques multi-acteurs: perspectives strategiques, Ed.PUG (2007).

[19] W. Guédria, Y. Naudet, D. Chen, Maturity model as decision support for enterprise interoperability, On the Move to Meaningful Internet Systems: OTM 2011 Workshops Lecture Notes in Computer Science 7046 (2011) 604-608, 2011.

[20] A. Osorio, L.M. Camarinha-Matos, Distributed process execution in collaborative networks, Robotics and Computer-Integrated Manufacturing 5 (2008) 647-655.

[21] L.M. Camarinha-Matos, H. Afsarmanesh, N. Galeano, A. Molina, Collaborative networked organizations-concepts and practice in manufacturing enterprises, Computers \& Industrial Engineering 57 ((1) August) (2009) 46-60.

[22] K. Ryu, E. Yucesan, CPM: A collaborative process modeling for cooperative manufacturers, Advanced Engineering Informatics 21 ((2) April) (2007) 231-239.

[23] R. Poler, J.E.J.E. Hernández, J. Mula, F.C. Lario, Collaborative forecasting in networked manufacturing enterprises, Journal of Manufacturing Technology Management 19 (4) (2008) 514-528.

[24] F. Alarcón, M.M.E. Alemany, A. Ortiz, Conceptual framework for the characterization of the order promising process in a collaborative selling network context International Journal of Production Economics 120 (1) (2009) 100-114.

[25] J. Gaudreault, J.M. Frayret, G. Pesant, Distributed search for supply chain coordination, Computers in Industry 60 (6) (2009) 441-451

[26] C. Schneeweiss, Distributed decision making in supply chain management, International Journal of Production Economics 84 (1) (2003) 71-83, 11.

[27] K.A. Arshinder, S.G. Deshmukh, Supply chain coordination: perspectives, empirical studies and research directions, International Journal of Production Economics 115 (2) (2008) 316-335.

[28] X.H. Li, Q.N. Wang, Coordination mechanisms of supply chain systems, European Journal of Operational Research 179 (1) (2007) 1-16, 16.

[29] P. Forget, T. Monteiro, S. D’Amours, J.-M. Frayret, Collaborative agent-based negotiation in supply chain using multi-behaviour agents, in: CIRRELT-2008-54, 2008, 1-21.

[30] P. Forget, P.S. D’Amours, S.J.-M. Frayret, J. Gaudreault, Study of the performance of multi-behaviour agents for supply chain planning, Computers in Industry 60 (2009) 698-708.

[31] M.M.E. Alemany, F. Alarcón, A. Ortiz, Impact of coordination mechanisms on the collaborative planning process components, International Federation for Information Processing 322 (2010) 185-192.

[32] M. Lejeune, N. Yakova, On characterizing the 4 C's in supply chain management, Journal of Operations Management 23 (2005) 81-100.

[33] I. Grossmann, Enterprise-wide optimization: A new frontier in process systems engineering, American Institute of Chemical Engineers 51 (7) (2005) 1846-1857.

[34] M.M.E. Alemany, F. Alarcón, F.C. Lario, J.J. Boj, An application to support the temporal and spatial distributed decision-making process in supply chain collaborative planning, Computers in Industry 62 (2011) 519-540.

[35] G.A. Garcia-Mireles, M. Angeles Moraga, F. Garcia, Development of maturity models: a systematic literature review, IET Digest 279 (2012)

[36] T. De Bruin, M. Rosemann, R. Freeze, U. Kulkarni, Understanding the main phases of developing a maturity assessment model, in: Proceedings of the 16th Australasian Conference on Information Systems, Sydney, Australia, 2005, pp. 1-10.

[37] C. Salviano, et al., A method framework for engineering process capability models in EuroSPI, in: The 16th European Systems and Softwaer Process Improvement and Innovation, Industry Proceedings, Alcalá, Madrid, (2009), pp. 625-636.

[38] T. Mettler, P. Rohner, R. Winter, Towards a classification of maturity models in information systems, in: Proceedings of itAIS 2009, Verona, 2009, 2009.

[39] J. Becker, R. Knackstedt, J. Pöppelbuß, Developing maturity models for IT management: a procedure model and its application, Business Information Systems (3) (2009) 249-260

40] A. Maier, J. Moultrie, J. Clarkson, Developing maturity grids for assessing organizational capabilities: practitioner guide, in: 4th International Conference on Management Consulting, Academy of Management (MCD 2009), Vienna, (2009), pp. 1-29.

[41] M. Van Steenbergen, et al., The design of focus area maturity models, in: $\mathrm{H}$ Winter, J.L. Zhao, S. Aier (Eds.), DESRIST, 2010, 317-332.

[42] C. Von Wangenheim, et al., Creating software process capability/maturity models IEEE Software 27 (4) (2010) 92-94.

[43] M. Kohlegger, R. Maier, S. Thalmann, Understanding maturity models results of a structured content analysis, in: Proceedings of I-KNOW '09 and I-SEMANTICS ‘09, 2-4 September 2009, Graz, Austria, 2009.

[44] A. Chakraborty, A. Kumar, Indian Institute of Management Calcuta, WPS No. 577 2005.

[45] R. Wendle, The maturity of maturity model research: a systematic mapping study, Information \& Software Technology 54 (12) (2012) 1317-1339.

[46] L. Cuenca, Marco Arquitectónico para la propuesta IE-GIP, in: Extensión de la Arquitectura CIMOSA. Aplicación a una empresa del sector cerámico, Universitat Politènica de València, 2009 ( $\mathrm{PhD}$ thesis).

[47] Lane Sea, Collective intelligence for competitive advantage: crowdsourcing and open innovation, in: Applied Information Management Master's Capstone Projects and Papers, 2010 http://hdl.handle.net/1794/10210.

[48] T.W. Malone, T.W.R. Laubacher, C.N. Dellarocas, Harnessing Crowds: Mapping the Genome of Collective Intelligence (Report No. 4732-09), MIT Sloan Research, 2009 .
[49] J.E. Salmos, Online Interviews in Real Time, Sage, Thousand Oaks, CA, 2010.

[50] M. Castelluccio, Collective Intelligence. Strategic Finance, Tech Forum, 2006 Retrieved from: http://www.imanet.org/pdf/11tools.pdf.

[51] J. Howe, The rise of crowdsourcing. Wired.com, (14.06). Retrieved from http:// www.wired.com/wired/archive/14.06/crowds.html?pg=3\&topic=crowds\&topic_ set; 2006.

[52] N. Hunt, S. McHale, A practical guide to the email interview, Qualitative Health Research 17 (10) (2007) 1415-1421

[53] Y.Y.L. Helgesson, M. Höst, K. Weyns, A review of methods for evaluation of maturity models for process improvement, Journal of Software: Evolution and Process 24 (4) (2011) 436-454.

[54] ASCER (Asociación Española de Fabricantes de Azulejos y de Pavimentos Cerá micos), Datos del sector de fabricacion de baldosas ceramicas en, 2007 http:// www.spaintiles.info/documentos (accessed: 17.11.2010).

[55] M.M.E. Alemany, D. Pérez, F. Alarcón, A. Ortiz, A. Boza, Planificación colaborativa en cadenas de suministro mediante programación matemática en entornos distribuidos, in: Presented at the I International Conference on Industrial Engineering and Industrial Management, 2007

[56] L. Cuenca, A. Boza, A. Ortiz, An enterprise engineering approach for the alignment of business and information technology strategy, International Journal of Computer Integrated Manufacturing 24 (1) (2011) 974-992.

[57] M.M.E. Alemany, J.J. Boj, J. Mula, F.C. Lario, Mathematical programming model for centralised master planning in ceramic tile supply chains, International Journal of Production Research 48 (2010) 5053-5074.

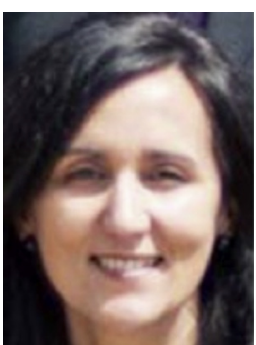

Llanos Cuenca is an assistant professor in Enterprise Management and Management Information Systems at the Universitat Politècnica de València (UPV) in Spain. She is a computer science engineer and received her $\mathrm{PhD}$ from the UPV. She is a member of Research Centre on Production Management and Engineering (CIGIP). She has participated as a researcher on several Spanish and European projects. At this moment, her research lines focus on Interoperability, Enterprise Architectures, Strategic Alignment and the use of ICT in these areas. As result of this research, she has published several papers in international conferences, books and and journals. She is editor of the "International Journal of Production Management and Engineering - IJPME".

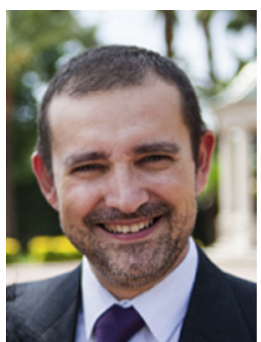

Andrés Boza is an assistant professor in Management Information Systems at the Universitat Politècnica de València (UPV) in Spain. He is a computer science engineer and received his PhD in SC Management and Enterprise Integration from the UPV. He is member of Research Centre on Production Management and Engineering (CIGIP) where he has participated in the doctoral program and in national and international projects about information systems for production management, SC management and performance measurement. He has published several papers in books, journals and international conferences in these fields. He is editor of the "International Journal of Production Management and Engineering - IJPME".

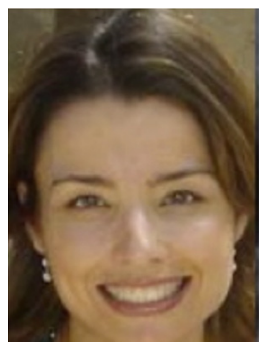

M.M.E. Alemany is an associate professor in Operations Management and Operations Research at the Universitat Politècnica de València (UPV) in Spain. She is an industrial engineer and received her PhD in Industrial Engineering from the UPV. She is a member of Research Centre on Production Management and Engineering (CIGIP) and has participated in several Spanish and European Projects. Currently, she is leading a Spanish Government Project. Her research is focused on Hierarchical Production Planning, Collaborative OP Process and SC Management under conceptual/quantitative perspective. She has several research papers in books, conferences and international journals.

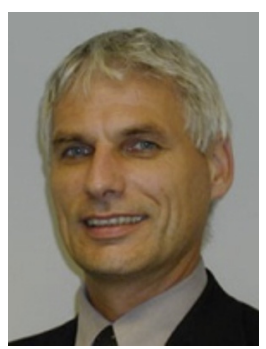

Dr. Jos J.M. Trienekens is an Associate Professor at TU/e Eindhoven (University of Technology - Eindhoven) in the area of software systems development. He studied Civil Engineering at The University of Technology in Delft. He obtained in 1994 a PhD. in software product quality at Eindhoven University of Technology. His current research interests include software process improvement, software quality and software metrics. He also addresses business performance aspects in his research. He is an associate member of the research school BETA at TU/e that focuses at operations management issues. Jos Trienekens published over the last ten years various books, papers in international journals and conference proceedings. 